\title{
Environmental effect and genetic influence: a regional cancer predisposition survey in the Zonguldak region of Northwest Turkey
}

\author{
Selahattin Kadir · A. Piril Önen-Hall • \\ S. Nihal Aydin · Cengiz Yakicier · Nurten Akarsu • \\ Murat Tuncer
}

Received: 20 December 2006/Accepted: 21 May 2007/Published online: 28 June 2007

(C) Springer-Verlag 2007

\begin{abstract}
The Cretaceous-Eocene volcano-sedimentary units of the Zonguldak region of the western Black Sea consist of subalkaline andesite and tuff, and sandstone dominated by smectite, kaolinite, accessory chlorite, illite, mordenite, and analcime associated with feldspar, quartz, opal-CT, amphibole, and calcite. Kaolinization, chloritization, sericitization, albitization, Fe-Ti-oxidation, and the presence of zeolite, epidote, and illite in andesitic rocks and tuffaceous materials developed as a result of the degradation of a glass shards matrix, enclosed feldspar, and clinopyroxene-type phenocrysts, due to alteration processes. The association of feldspar and glass with smectite
\end{abstract}

S. Kadir $(\bowtie)$

Department of Geological Engineering,

Eskisehir Osmangazi University,

26480 Eskisehir, Turkey

e-mail: skadir_ogu@yahoo.com

A. P. Önen-Hall

Department of Geological Engineering,

Middle East Technical University,

06531 Ankara, Turkey

S. N. Aydin

General Directorate of Mineral Research and Exploration

(MTA), 26480 Ankara, Turkey

C. Yakicier

Department of Molecular Biology and Genetics,

Bilkent University, Ankara, Turkey

N. Akarsu · M. Tuncer

Department of Pediatrics, Pediatric Hematology,

Gene Mapping Laboratory,

Hacettepe University, Ankara, Turkey

M. Tuncer

The Ministry of Health Cancer Control Department,

Ankara, Turkey and kaolinite, and the suborientation of feldspar-edged, subparallel kaolinite plates to fracture axes may exhibit an authigenic smectite or kaolinite. Increased alteration degree upward in which $\mathrm{Al}, \mathrm{Fe}$, and $\mathrm{Ti}$ are gained, and $\mathrm{Si}, \mathrm{Na}$, $\mathrm{K}$, and $\mathrm{Ca}$ are depleted, is due to the alteration following possible diagenesis and hydrothermal activities. Micromorphologically, fibrous mordenite in the altered units and the presence of needle-type chrysotile in the residential buildings in which cancer cases lived were detected. In addition, the segregation pattern of cancer susceptibility in the region strongly suggested an environmental effect and a genetic influence on the increased cancer incidence in the region. The most likely diagnosis was Li-Fraumeni syndrome, which is one of the hereditary cancer predisposition syndromes; however, no mutations were observed in the p53 gene, which is the major cause of Li-Fraumeni syndrome. The micromorphology observed in the altered units in which cancer cases were detected may have a role in the expression of an unidentified gene, but does not explain alone the occurrence of cancer as a primary cause in the region.

Keywords Alteration minerals - Genetic influence · Geochemistry · Health effects · Mineralogy · Turkey · Volcanosedimentary units $\cdot$ Zonguldak

\section{Introduction}

The study area was situated in the Zonguldak region near Gökçeler Village in the western Black Sea Region of Turkey, which is composed mainly of volcano-sedimentary units. These units exhibit soft morphology and surface weathering. In nature, alteration minerals in different rock units of different geological environments, such as 
marine, lacustrine, fluvial, detrital, etc., develop either by direct precipitation from solution or transformation from other precursor minerals and amorphous materials, or detritally due to diagenesis, weathering, or hydrothermal processes (Velde 1985). Hydrothermal alteration is very common in the Eastern Black Sea Region due to volcanogenic massive sulfide mineralization (Çağatay 1993; Akçay 2004; Çelik et al. 1999) and in situ alteration of volcanic units in different parts of the region (Yalçın and Gümüşer 2000; Abdioğlu and Arslan 2005; Arslan et al. 2006). To the best of our knowledge, no detailed mineralogical research concerning the alteration process and distribution of alteration products were previously conducted in the Zonguldak region. Moreover, the proportional increase in human cancer in the area led us to undertake this study with the support of Turkish Ministry of Health. It is known that inhalation of a variety of mineral fibers are hazardous to health, especially when the exposure is high and continued over a long period of time (Skinner et al. 1988). Nevertheless, domestic or general environmental exposure is also possible and can cause serious damage. Although the lungs and surrounding tissues are the primary targets during inhalation, there may be subsequent reactions in many other parts of the body. The known hazardous fibers are asbestos and the fibrous zeolite, namely erionite. There are other fibers such as mordenite, whose contributions to human disease are as yet not completely recognized. Amphibole asbestos and erionite are considered more pathogenic than chrysotile asbestos, or white asbestos, which is the most common and widely used type. It has curly fibers, and is a serpentine group mineral. Chrysotile has the fastest clearance from the body, and it is likely that diseases are mainly associated with amphibole exposure (Hillerdal 2003). Exposure to hazardous minerals leading to disease is usually occupational; however, there are other possibilities, such as environmental pollution due to industrial processes, buildings containing asbestos, and the local geological occurrence of mineral fibers. Furthermore, many soils provide an environment for diseases due to their chemical, physical, and mineralogical diversity, which depend on many interrelated factors, such as parent rock composition and mineralogy, topography, climate, vegetation, soil moisture, organic matter content, supply of nutrients, and many other factors (Bultman et al. 2005). In order to understand the effect of environment on health, the environmental media such as the lithology of the area, air, water, and soil/food should be studied. This study concentrated mainly on the Zonguldak region's fresh and altered rocks, and their soils, with regard to their petrography, mineralogy, and geochemistry. Additionally, the possible effects of environmental geology on human health are discussed. The mineralogy and crystallography of the concrete material used in buildings in the residential areas of Gökçeler Village in which human cancer cases were identified were also studied. Since Gökçeler Village is one of the geographic areas where the incidence of cancer differs strikingly in comparison to the other regions of Turkey, and since most cancers are likely to be caused by a combination of different factors, in this study the effects of both genetic and environmental factors are discussed.

\section{Materials and analytical techniques}

Geological techniques

Fieldwork was conducted using existing geological maps of Gökçeler Village modified from a 1:25.000 scale map obtained from the General Directorate of Mineral Research and Exploration of Turkey (MTA) (Yergök et al. 1987). In order to identify the lateral and vertical distribution of the alteration products in Gökçeler Village and their relationship to human cancer in the area, 59 samples were collected from different representative lithologies of the volcano-sedimentary units for petrographical, mineralogical, and geochemical determinations (Fig. 1).

Polarized-light microscopy (Leitz Laborlux 11 Pol) studies were carried out on fresh, partly altered, and altered volcano-sedimentary samples. Mineralogical characteristics of the representative samples were further determined by X-ray powder diffractometry (XRD) (Rigaku-Geigerflex) and differential thermal analysis-thermal gravimetry (DTA-TG-Rigaku TAS $100 \mathrm{E}$ model) at MTA, and scanning electron microscopy (SEM-EDX) (JEOL JSM 84AEDX) was conducted at the Metallurgical Engineering Department of Middle East Technical University. XRD analyses were performed using $\mathrm{CuK} \alpha$ radiation and a scanning speed of $1^{\circ} 2 \theta / \mathrm{min}$. Unoriented mounts of powdered whole-rock samples were scanned to determine the mineralogy of the bulk sample. Samples were prepared for clay mineral analysis (size fraction $<2 \mu \mathrm{m}$ ) by separation of the clay fraction by sedimentation, followed by centrifugation of the suspension after overnight dispersion in distilled water. The clay particles were dispersed by ultrasonic vibration for about $15 \mathrm{~min}$. Oriented specimens of the $<2-\mu \mathrm{m}$ fraction were prepared of each sample in this way: air drying, ethylene glycol-solution at $60^{\circ} \mathrm{C}$ for $2 \mathrm{~h}$, thermal treatment at 350 and $550^{\circ} \mathrm{C}$ for $2 \mathrm{~h}$, respectively, $\mathrm{K}$-saturation ( $\mathrm{K}$ acetate), and finally, removing $\mathrm{K}$-acetate by repeated washings and addition of ethylene glycol without allowing the clay to dry (MacEwan and Wilson 1980; Wilson 1987). Semi-quantitative relative abundances of rock-forming minerals were obtained by using the 

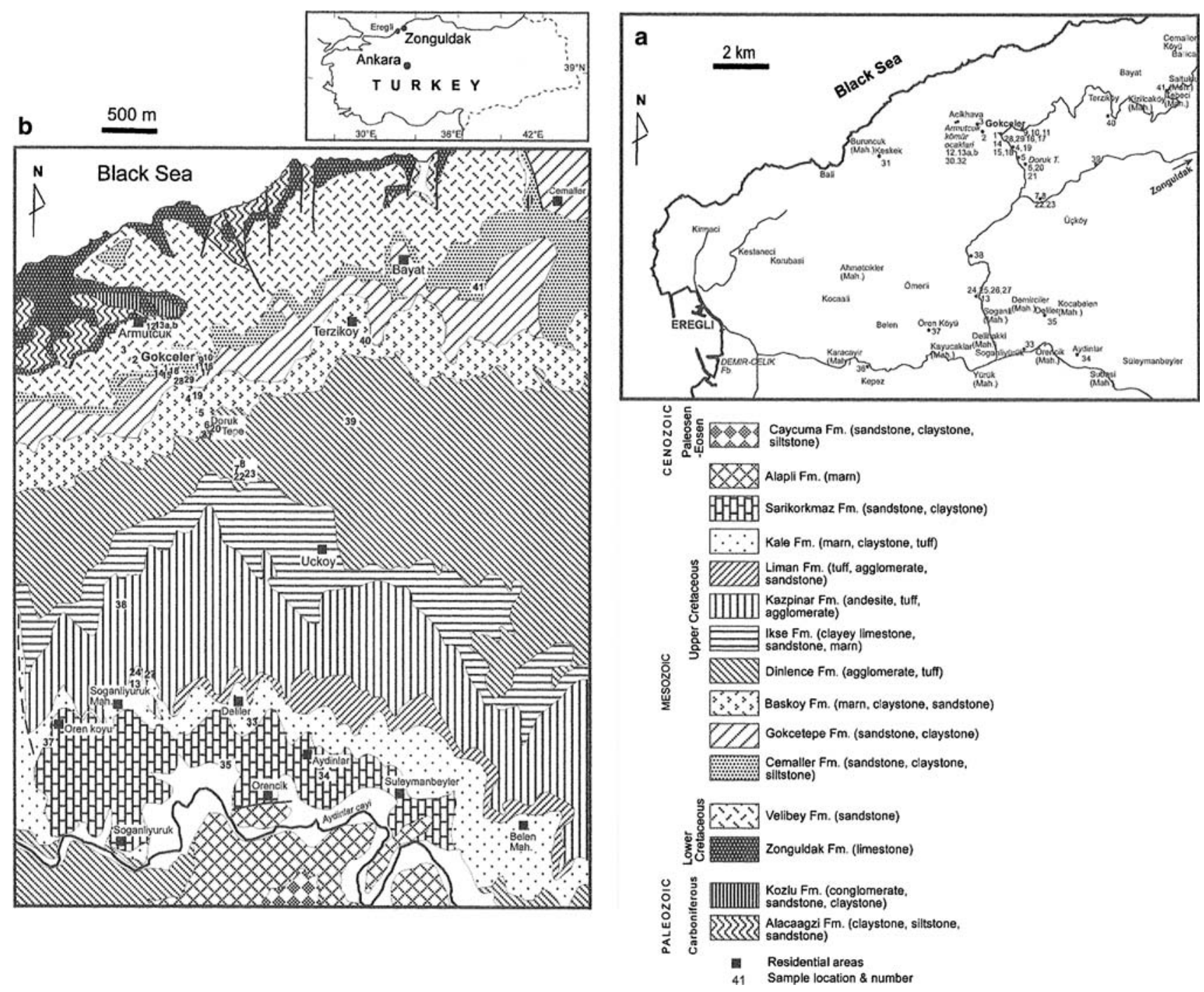

Fig. 1 Location of the study area (a) and simplified geological map (b) of the Zonguldak region (after Yergök et al. 1987)

external method of Brindley (1980), whereas the relative abundances of clay-mineral fractions were determined using their basal reflections and the intensity factors of Moore and Reynolds (1989). The relative error of this method is $<15 \%$. Representative clay-dominated bulk samples were prepared for SEM-EDX analysis by sticking the fresh, broken surface of the sample onto an aluminum sample holder with double-sided tape and thinly coating it with a gold film $(\sim 350 \AA)$. DTA-TG curves were recorded using $10 \mathrm{mg}$ of powdered sample in a Pt sample holder at an average rate of $10^{\circ} \mathrm{C} / \mathrm{min}$, with an alumina reference.

Chemical analyses of 22 whole-rock samples were further analyzed for major, trace, and rare earth elements (REE) by inductively coupled plasma atomic emission spectrometry (ICP-AES) at the Department of Geology, Royal Holloway University of London. $\mathrm{Si}, \mathrm{Al}, \mathrm{Zr}, \mathrm{Fe}, \mathrm{Mg}$, $\mathrm{Ca}, \mathrm{Na}, \mathrm{K}, \mathrm{Ti}, \mathrm{P}, \mathrm{Mn}, \mathrm{Ba}, \mathrm{Co}, \mathrm{Cr}, \mathrm{Cu}, \mathrm{Li}, \mathrm{Ni}, \mathrm{Pb}, \mathrm{Sc}, \mathrm{Sr}, \mathrm{V}$, and $\mathrm{Zn}$ were analyzed by ICP-AES using a Perkin Elmer Optima 3300R. Cs, Nb, Rb, Ta, Th, Tl, U, and Y, and the rare earth elements $\mathrm{La}, \mathrm{Ce}, \mathrm{Pr}, \mathrm{Nd}, \mathrm{Sm}, \mathrm{Eu}, \mathrm{Gd}, \mathrm{Dy}, \mathrm{Ho}, \mathrm{Er}$, $\mathrm{Yb}$, and Lu were analyzed by ICP mass spectrometry using a Perkin Elmer Elan 5000. The instruments were calibrated with natural and synthetic standards. In the analyses, detection limits ranged from 0.01 to $0.1 \mathrm{wt} \%$ for major elements, 0.1 to $5 \mathrm{ppm}$ for trace elements, and 0.01 to $0.5 \mathrm{ppm}$ for REE.

\section{Genetic evaluation}

A field study was performed for pedigree analysis in Gökçeler Village and surrounding villages. Clinical records of cancer patients were obtained from nearby hospitals and mainly, Numune Hospital, Ankara, Turkey. Accumulation 
of different types of cancers in the same region was observed. The p53 gene, which is the major cause of cancer predisposition syndromes, was screened for a mutation. For this analysis, peripheral blood was obtained from the index patient with her consent. Genomic DNA was isolated from whole blood with the QIAamp Blood Kit (Qiagen, Turkey), according to the manufacturer's instructions. Genomic DNA was subjected to PCR amplification for exons 2-11 of the p53 gene with the specific primers. PCR products were purified with Montage $\mathrm{PCR}_{96}$ Cleanup Kit (Millipore) and directly sequenced. Sequencing reactions were performed using an ABI310 DNA Sequencer (Perkin-Elmer Applied Biosystems), according to the instructions of the manufacturer.

\section{Geological setting}

The Istanbul Zone consists of various basement rock series; a Paleozoic sedimentary sequence (Istanbul-Zonguldak Paleozoic succession), a Triassic terrestrial sedimentary unit, a Middle Jurassic clastic unit, and an Upper JurassicLower Cretaceous platform carbonate sequence (Tüysüz 1999; Tüysüz et al. 2004). The area that was studied around Gökçeler Village in the Zonguldak region is within the Zonguldak Basin of the Istanbul Zone (Fig. 1).

The Zonguldak Basin, which extends from Ereğli to Amasra, is overlain by the latest Cretaceous-Eocene sediments of the Devrek Basin to the south, and is bounded by the Cide Uplift in the northeast (Fig. 1). The Paleozoic sedimentary sequences are the oldest units in the region and are represented by the Alacaağz1 Formation (claystone, siltstone, and sandstone) and the Kozlu Formation (conglomerate, sandstone, claystone, and coal-rich) (Yergök et al. 1987). Lower and Upper Cretaceous sedimentary rocks are separated by a regional Cenomanian unconformity (Tüysüz 1999). In the studied region, according to Yergök et al. (1987) (Fig. 1), the Lower Cretaceous sequences are represented by formations like Zonguldak (limestone) and Velibey (sandstone). The Upper Cretaceous formations are the Cemaller Formation (sandstone, claystone, and siltstone), the Gökçetepe Formation (sandstone and claystone), the Başköy Formation (marn, claystone, and sandstone), the Dinlence Formation (agglomerate and tuff), the İkse Formation (clayey limestone, sandstone, and marn), the Kazpinar Formation (andesite, tuff, and aglomerate), the Liman Formation (tuff, aglomerate and sandstone), the Kale Formation (marn, claystone and tuff), the Sarıkorkmaz Formation (sandstone and claystone), and the Alapli Formation (marn). The Paleocene-Eocene unit is represented by the Çaycuma Formation (sandstone, claystone and siltstone).

\section{Results}

Mineralogical results

\section{Petrographical determinations}

Andesites are usually holocrystalline and porphyritic, and phenocrysts are commonly plagioclase (oligoclase), clinopyroxene (diopside and augite), biotite, and opaques (Fig. 2a-f). Different degrees of alteration are common to all andesites and are typically replaced by low-grade secondary assemblages. Generally, clinopyroxenes are replaced by hornblende and chlorite. Basaltic hornblende is also common and is rimmed and replaced by Fe-Ti oxide minerals. Chlorite, biotite, uralite, clay minerals, calcite, and Fe-Ti oxide minerals are the most common alteration products. Major groundmass minerals are plagioclase and opaques. Albite + epidote + chlorite + calcite + zeolite assemblages indicate greenschist facies. Rare vesicules are filled and locally rimmed by chlorite, calcite, and zeolite minerals. Groundmass contains volcanic glass for both formations and is replaced by clay minerals and $\mathrm{Fe}-\mathrm{Ti}$ oxides in different amounts. Alteration types are commonly kaolinization, biotitization, and oxidation, as well as weak chloritization and sericitization. Zeolite is also found as a replacement product of plagioclase. Apatite is the accessory mineral phase. Groundmass consists of plagioclase, biotite, clinopyroxene and opaques. Tuff samples are usually lithic tuff and also vitrified tuff (Fig. 2b, d). The sample ZG40a shows flow texture.

Sandstone samples are known as arkose, sub-arkose, and lithic arkose, according to the classification of Folk (1974) (Fig. 2e). They usually contain plagioclase and quartz, in addition to clinopyroxene, calcite, clay minerals, opaques, biotite, hornblende, and basaltic hornblende, and rock fragments that include volcanic rock, quartzite, and chert. Glauconite and epidote are the rare minerals. Cement is made up of common calcite, and chlorite and clay minerals. Fe-Ti oxidation is very strong and the rocks are commonly red in color. ZG25 is represented by micrite-siltstone intercalations and contains fossils.

Soil samples from various formations contain plagioclase, quartz, amphibole, clinopyroxene, and opaques, as well as rare epidote, calcite, and glauconite, and rock fragments of siltstone, volcanic rocks, and quartzites (Fig. 2f). Clay minerals and Fe-Ti oxides are the most common cement materials. Opaque minerals are commonly magnetite, hematite, pyrite, rutile, limonite, and rare marcasite, chalcopyrite, goethite, lepidocrosite, in addition to some coal and organic material. Rutile is usually replaced by leucoxene, and magnetite is replaced by hematite. 
Fig. 2 Photomicrographs of (a) andesite, exhibiting chloritization, kaolinization, and $\mathrm{Fe}-\mathrm{Ti}$ oxidation (ZG38b); (b) altered andesite, showing chloritization, clinopyroxene replaced by hornblende and basaltic hornblende, and $\mathrm{Fe}-\mathrm{Ti}$ oxidation (ZG39b); (c) vitrified tuff, showing development of biotite plates between plagioclase phenocrysts, which are exhibiting chloritization and $\mathrm{Fe}-\mathrm{Ti}$ oxidation (ZG40a); (d) lithic tuff, showing chloritization, clinopyroxene replaced by hornblende, and $\mathrm{Fe}-$ Ti oxidation (ZG39f); (e) lithic arkose, showing clinopyroxene replaced by hornblende, plagiocalse, and quartz, and chloritization and $\mathrm{Fe}-\mathrm{Ti}$ oxidation (ZG37a); (f) soil, showing Fe-oxidation (ZG24)
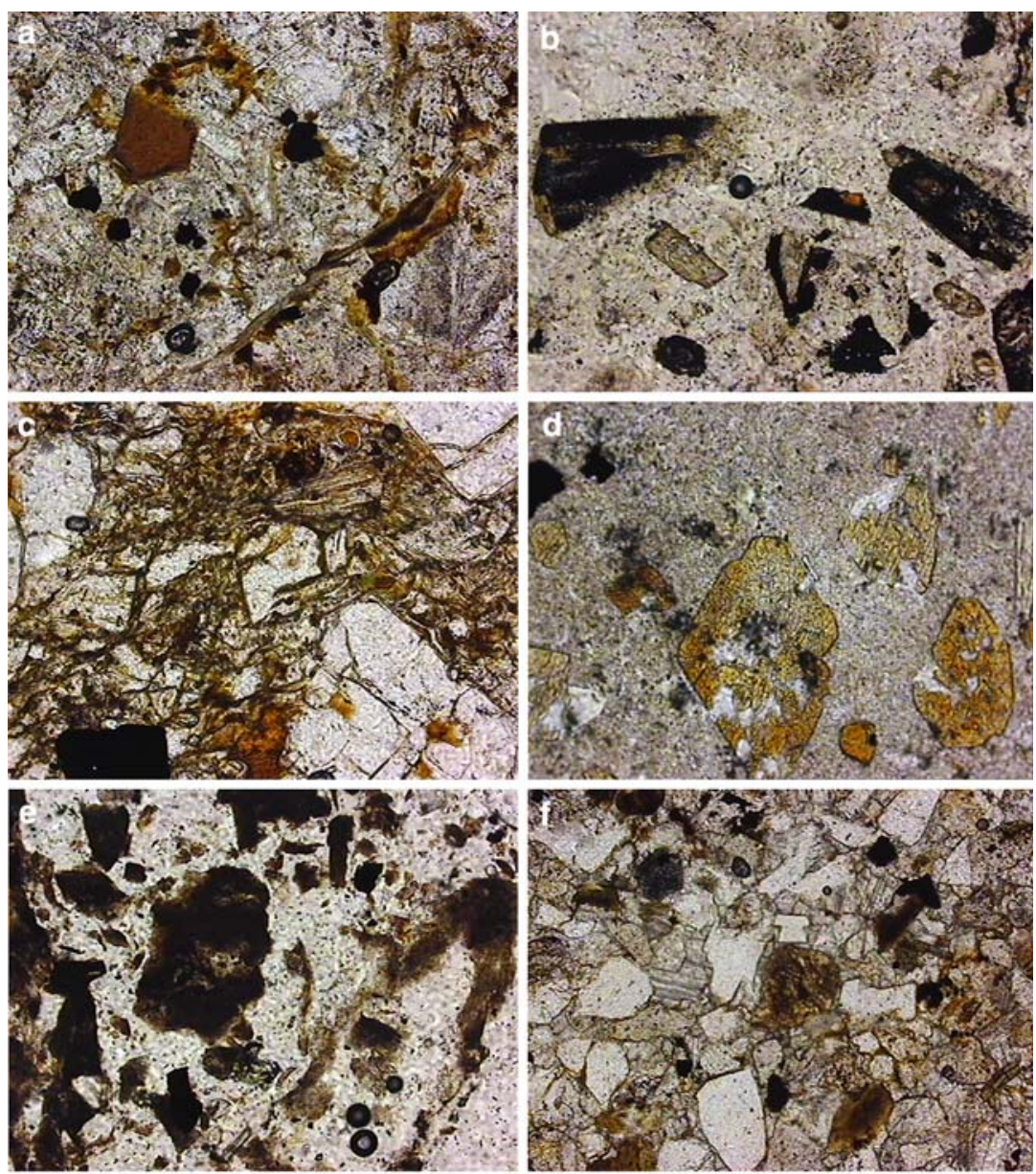

$100 \mu \mathrm{m}$

\section{XRD determinations}

The mineralogical composition of the samples from fresh, partly altered and altered samples, of different volcanosedimentary units were examined by X-ray diffraction (Table 1). Smectite, chlorite, kaolinite, illite, mordenite, and analcime, are the main alteration products, accompanied by feldspar, quartz, opal-CT, amphibole, and calcite, as well as accessory olivine, serpentine, and dolomite in places. Association of these minerals, mainly with feldspar, quartz, and opal-CT, may reveal that there is a genetic relationship between them. Moreover, it is found that the neoformed altered minerals increase upward of the volcanosedimentary units' outcrops, where calcite is either rare or absent. Therefore, there is an inverse relationship between calcite, which is the dominant carbonate mineral, and feldspar, quartz, and opal-CT, as well as alteration product minerals. Smectite is the dominant clay mineral in the samples and is associated with small amounts of chlorite in places. Although kaolinite is the dominant clay mineral in the ZG39c, ZG39d and ZG39e samples, it is rarely associated with smectite and chlorite in some samples.
Well-crystallized smectite is distinguished by a very sharp peak of 14.7-15 $\AA$, which expands to $17.6 \AA$ with ethylene glycol treatment (Fig. 3A). The sharpening of the reflection reduced sharply to $9.2 \AA$ upon heating to $350^{\circ} \mathrm{C}$. Additional heating to $550^{\circ} \mathrm{C}$ resulted in further change. The $060 \mathrm{~d}$-spacing values of smectite reflect $1.50 \AA$, indicating dioctahedral character.

Kaolinites are determined by broad continuous reflections at $7.2,4.48,3.54,2.53,1.68$, and $1.48 \AA$, and the disappearance of 4.18 and $3.84 \AA$ peaks may indicate either $7.3 \AA$-halloysite or highly disordered kaolinite rather than ordered kaolinite (Fig. 3B), which is similar to what was reported by MacEwan and Wilson (1980) and Wilson (1987). The basal reflection of kaolin minerals was not affected by ethylene glycol, but the intensity of the reflection reduced upon heating to $350^{\circ} \mathrm{C}$ and collapsed at about $550^{\circ} \mathrm{C}$. The basal reflection of the mineral is moved to $14.46 \AA$ following treatment with strong potassium acetate due to the presence of kaolinite. Additionally, reflection of strong $7.3 \AA$ and poor $11.8 \AA$ peaks after washing $\mathrm{K}$-acetate with water and adding ethylene glycol before drying the sample indicates the presence of domi- 
Table 1 Mineralogical variation through stratigraphic sections of the Gökçeler Village area

\begin{tabular}{|c|c|c|c|c|c|c|c|c|c|c|c|c|c|c|c|c|}
\hline Sample no & $\mathrm{smc}$ & chl & kao & gibb & ill & mord & anal & tal & $\mathrm{fds}$ & $\mathrm{qtz}$ & op-ct & amp & oliv & serp & cal & dol \\
\hline ZG1-A & + & + & & & + & & & & ++ & ++ & acc & & & & & \\
\hline ZG 1B & + & acc & & & acc & & & & ++ & ++ & acc & & & & & \\
\hline ZG 2 & & & & & & & & & acc & +++++ & acc & & & & & \\
\hline ZG 3A & & + & ++ & & & & & & acc & +++ & acc & & & & & \\
\hline ZG 3B & + & + & ++ & & & & & & & ++ & acc & & & & & \\
\hline ZG 4 & + & & & & + & + & & & + & + & acc & & & & ++ & \\
\hline ZG 5 & ++ & & & & & acc & & & + & ++ & acc & & & & + & \\
\hline ZG 6 & ++ & & & & acc & acc & & & +++ & acc & acc & & & & & \\
\hline ZG 7 & & & & & & acc & & & & + & acc & & & & ++++ & \\
\hline ZG 8 & ++ & & & & acc & + & & & + & +++ & + & & & & & \\
\hline ZG 9 & acc & & & & acc & & & & acc & ++++ & + & & & & & \\
\hline ZG 10 & & & & & & & & & & + & & & & & ++++ & \\
\hline ZG 11 & & + & + & & & + & + & & + & & + & & & & + & \\
\hline ZG 12 & + & acc & & & & acc & & & acc & acc & & & & & ++++ & \\
\hline ZG 13 & +++ & & & & & acc & & & + & acc & + & & & & + & \\
\hline ZG13A & & & & & acc & & & & acc & + & & & & & ++++ & acc \\
\hline ZG13B & & + & & & + & & & & acc & +++ & acc & & & & & \\
\hline ZG14 & + & + & & & + & & & & acc & ++ & acc & & & & + & \\
\hline ZG16 & + & + & & & + & + & ++ & & + & + & acc & & & & + & \\
\hline ZG17 & ++ & & + & & & + & & + & + & & + & & & & & \\
\hline ZG18 & + & & & & acc & + & & & acc & ++ & + & & & & + & \\
\hline ZG19 & ++ & & & & & acc & & acc & ++ & acc & acc & + & & & acc & \\
\hline ZG20 & acc & & & & acc & & & & ++ & & acc & + & & & & \\
\hline ZG21 & ++ & & + & & acc & & & & ++ & & acc & & & & & \\
\hline ZG22 & & & & & acc & & & & acc & + & & & & & ++++ & \\
\hline ZG23 & ++ & & & & + & acc & & & acc & ++ & + & & & & & \\
\hline ZG24 & +++ & & & & acc & + & & & + & & + & acc & & & + & \\
\hline ZG25 & + & & & & acc & & & & acc & + & + & & & & +++ & \\
\hline ZG26 & + & & & & + & acc & & & +++ & + & + & & & & & \\
\hline ZG27 & + & & & & + & & & & +++ & acc & + & & & & & \\
\hline ZG28 & + & & & & & acc & +++ & & acc & + & + & & & & & \\
\hline ZG29 & acc & & & & acc & & & & & + & + & & & acc & +++ & \\
\hline ZG30 & & & & & & & & & & & +++++ & & & & & \\
\hline ZG31A & + & acc & & & acc & & & & acc & ++ & + & & & & ++ & \\
\hline ZG31B & acc & & & & acc & & & & + & +++ & + & & & & & \\
\hline ZG32A & & & + & & + & & & & acc & ++ & + & & & & & \\
\hline ZG32B & & & & & & & & & & & +++++ & & & & & \\
\hline ZG33A & + & acc & & & & acc & & & ++ & + & + & & & & & \\
\hline ZG33B & + & & & & & & acc & & acc & + & & & & & +++ & \\
\hline ZG34A & acc & & & & & & & & + & acc & & acc & & & +++ & \\
\hline ZG34B & +++++ & & & & & acc & + & & + & & acc & & & & & \\
\hline ZG35 & ++ & & & & acc & acc & & & acc & + & + & & & & ++ & \\
\hline ZG36A & + & & & & acc & acc & & & acc & ++ & + & & & & ++ & \\
\hline ZG36B & ++++ & & & & acc & + & + & & & & + & acc & & & & \\
\hline ZG37A & +++ & & & & acc & & & & + & + & + & acc & & & + & \\
\hline ZG37B & + & & & & acc & & & & + & + & acc & acc & & & ++ & \\
\hline ZG38A & & + & & & + & & & & +++ & + & + & & & & & \\
\hline ZG38B & & & & & + & & & & +++ & + & + & & & & & acc \\
\hline
\end{tabular}


Table 1 continued

\begin{tabular}{|c|c|c|c|c|c|c|c|c|c|c|c|c|c|c|c|}
\hline Sample no & $\mathrm{smc}$ & chl & kao & gibb & ill & mord & anal tal & fds & qtz & op-ct & amp & oliv & serp & cal & dol \\
\hline ZG38C & + & & + & & acc & & & ++ & + & + & & & & & \\
\hline ZG39A & & & & & & acc & & + & ++ & & + & + & & & \\
\hline ZG39B & + & & + & acc & acc & & & acc & + & + & & & & & \\
\hline ZG39C & & & ++++ & & acc & & & & & & & & & & \\
\hline ZG39D & acc & & +++ & & + & & & & ++ & + & & & & & \\
\hline ZG39E & & & ++++ & & & acc & & + & acc & + & + & & & & \\
\hline ZG39F & +++ & & & & acc & ++ & & + & & + & + & & & acc & \\
\hline ZG40A & + & & & & & + & & + & + & + & & & & & \\
\hline ZG40B & +++ & & & & & + & & + & + & + & acc & & & & \\
\hline ZG41A & + & acc & & & acc & & + & + & ++ & & & & & & \\
\hline ZG41B & + & & & & + & acc & & acc & +++ & + & & & & & \\
\hline
\end{tabular}

$s m c$ smectite, $c h l$ chlorite, kao kaolinite, gibb gibbsite, ill illite, mord mordenite, anal analcime, tal talc, fds feldspar, qtz quartz, op-ct opal-ct, amph amphibole, oliv olivine, serp serpentine, cal calcite, dol dolomite, acc accessory, + relative abundance of mineral

nant kaolinite and a small amount of halloysite, respectively. Increased XRD background in most of the samples may indicate the presence of amorphous and organic materials (Jones and Segnit 1971; Iijima 1980; Iijima and Tada 1981). Mordenite is determined by 9.1, 4.53, 4.00, 3.48 , and $3.39 \AA$ peaks, and analcime is determined by $5.60,3.43$, and $2.92 \AA$ peaks.

\section{SEM-EDX determinations}

Feldspar is generally characterized as very large, blocky, and partly to highly altered, having dissolution cavities and, in places, euhedral and exhibit zoning. Development of alteration products on skeletal remnants of feldspar and in dissolved cavities of feldspar layers was observed (Fig. 4a, b). Generally, development of spongy and cornflakes structures of smectite in dissolution voids and micro fractures of volcanic materials was determined (Fig. 4c-e). The edges of smectite plates become narrower, forming fibrous structures, which probably represent the formation of illite from smectite by transformation mechanism. Some of these blocks are highly degradated and form subparallellayered structures along the c-axis of the crystal, and further alteration result in development of subparallel and irregular kaolinite plates (Fig. 4f, g). The size of the plates increased from the feldspar wall toward the central part of the fractures, where the plates exhibit suborientation toward the fracture axis.

The occurrence of subrounded aggregates having grain sizes between 2 and $20 \mu \mathrm{m}$ in diameter on the altered surface possibly represents microorganisms (Fig. 4h), based on their morphologies and compositions of mainly $\mathrm{C}$ obtained by EDX analyses. These subrounded aggregates are covered by spongy materials, and are individual and interwoven of very thin fibers of mordenite, in places
(Fig. 4h). Furthermore, some of these fibers are developed in the micro fracture and dissolution void of the volcanic materials (Fig. 4i). Highly altered volcanic units (soil) have approximately $15 \%$ porosities and enclose filamentous structures (Fig. 4j). Moreover, oriented flexible continuous layers were observed in the ZG13 sample, possibly resembling the occurrence of flakes of biotite, which is compacted between the volcano-sedimentary grains (Fig. 4k).

It is found that some of the concrete buildings in the residential areas of Gökçeler Village are dominated by needle-type crystals $(0.2 \times 5 \mu \mathrm{m})$, which were determined as chrysotile (Fig. 41), based on petrographical, XRD, and EDX analyses.

\section{Differential thermal analysis-thermal gravimetry (DTA-TG)}

The DTA-TG curves of the smectite (ZG34b) sample exhibit three main endothermic peaks; at $149^{\circ} \mathrm{C}$ (weight loss: $11.7 \%$ ), $561^{\circ} \mathrm{C}$ (weight loss: $3.2 \%$ ), and $848^{\circ} \mathrm{C}$ (weight loss: $2.0 \%$ ), and an exothermic ridge at $871^{\circ} \mathrm{C}$ (Fig. 5a). The first large asymmetric endothermic peak is due to the elimination of hygroscopic and zeolitic waters. The second and third endothermic peaks are due to dehydroxylation. The last endothermic peak is followed by an exothermic peak due to recrystallization into a new phase, which is possibly enstatite (MacKenzie 1957; Smykatz-Kloss 1974; Kadir and Karakaş 2002).

The DTA-TG curves of the kaolinite (ZG39c) sample show two endothermic peaks; at $150^{\circ} \mathrm{C}$ (weight loss: $3.8 \%$ ) and $552.5^{\circ} \mathrm{C}$ (weight loss: $7.8 \%$ ), and an exothermic peak at $927^{\circ} \mathrm{C}$ (weight loss: $1.8 \%$ ) (Fig. 5b). The first endothermic peak is small and wide, possibly due to the loss of adsorbed water as well as some interlayer water, and the 


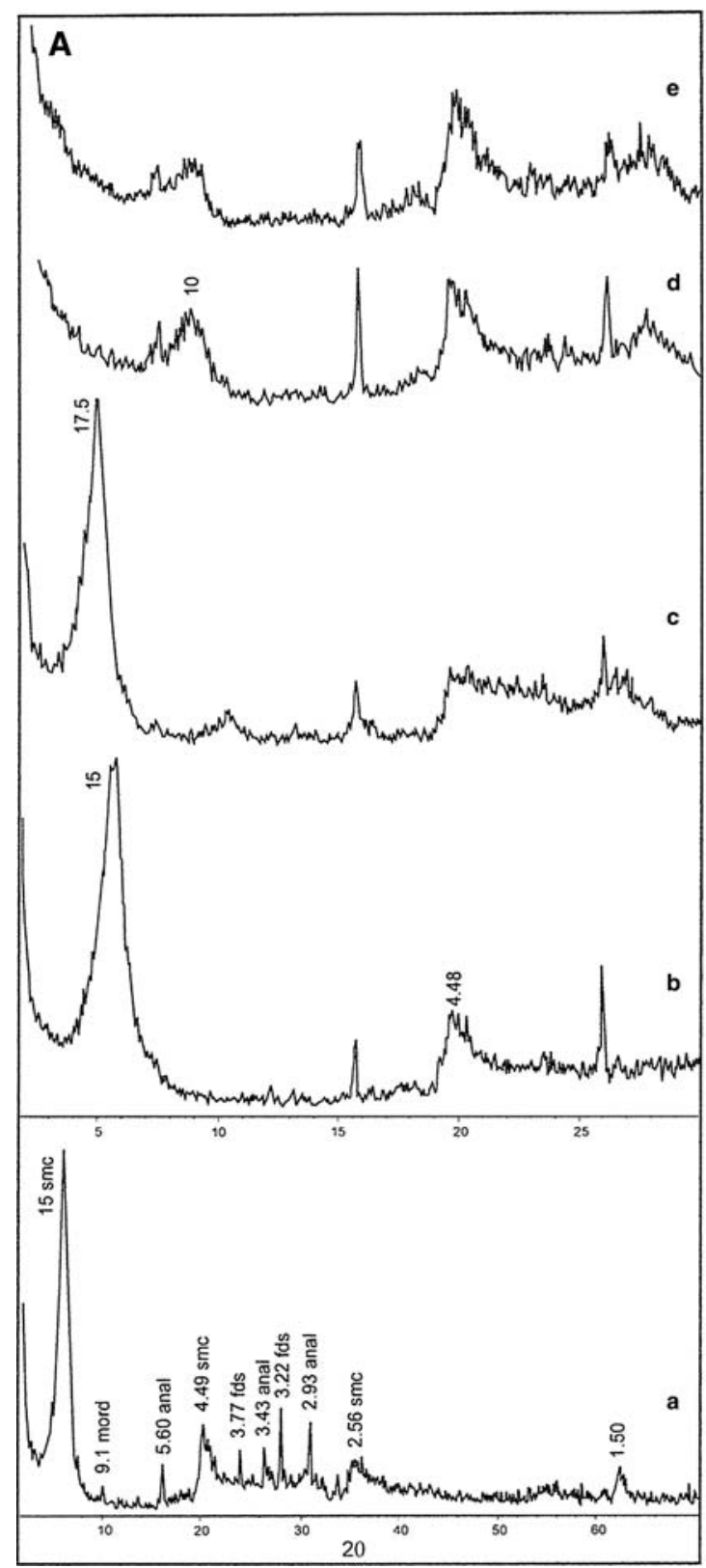

Fig. 3 X-ray diffraction patterns of the Gökçeler Village materials. A Smectite (ZG34b), B Kaolinite-dominated (ZG39c) samples: (a) unoriented; $(b)$ air-dried; $(c)$ ethylene-glycol-solvated; $(d)$ heated 350/ $2 \mathrm{H} ;(e)$ heated $550 / 2 \mathrm{H} ;(f)$ strong K-acetate treatment; $(g)$ removal of

large main strong symmetric endothermic peak at $552.5^{\circ} \mathrm{C}$ is due to the dehydration and decomposition (dehydroxylation) of the mineral, similar to what was reported by MacKenzie (1957), Smykatz-Kloss (1974) and Paterson and Swaffield (1987). The last medium-strong exothermic peak is probably due to recrystallization of alumina and/or mullite. Although the first endothermic peak may reveal the presence of some $7 \AA$-halloysite, the strong, symmetric endothermic peak of the dehydration peak is indicative of well-crystallized kaolinite (MacKenzie 1957).

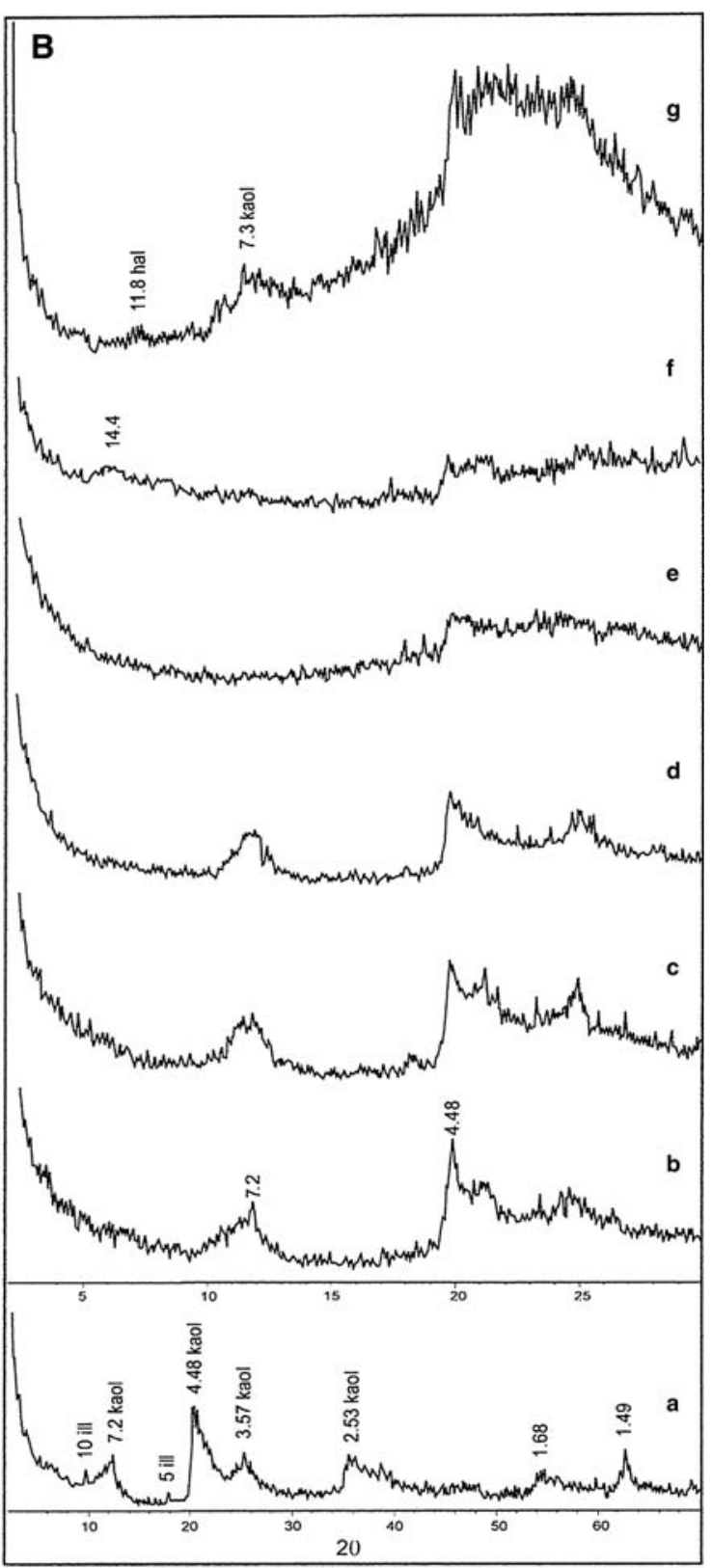

K-acetate by washing and addition of ethylene glycol. $s m c$ smectite, kaol kaolinite, hal halloysite, anal analcime, mord mordenite, fds feldspar

Geochemical results

\section{General geochemistry}

The results of the representative samples from the Zonguldak region are presented in Table 2. The major element data from andesites and tuffs give rather high LOI as a chemical alteration effect; therefore, incompatible elements (particularly Ti, P, Zr, Y, Hf, Th, Ta, and REE) are used to determine the primary chemical features of these 

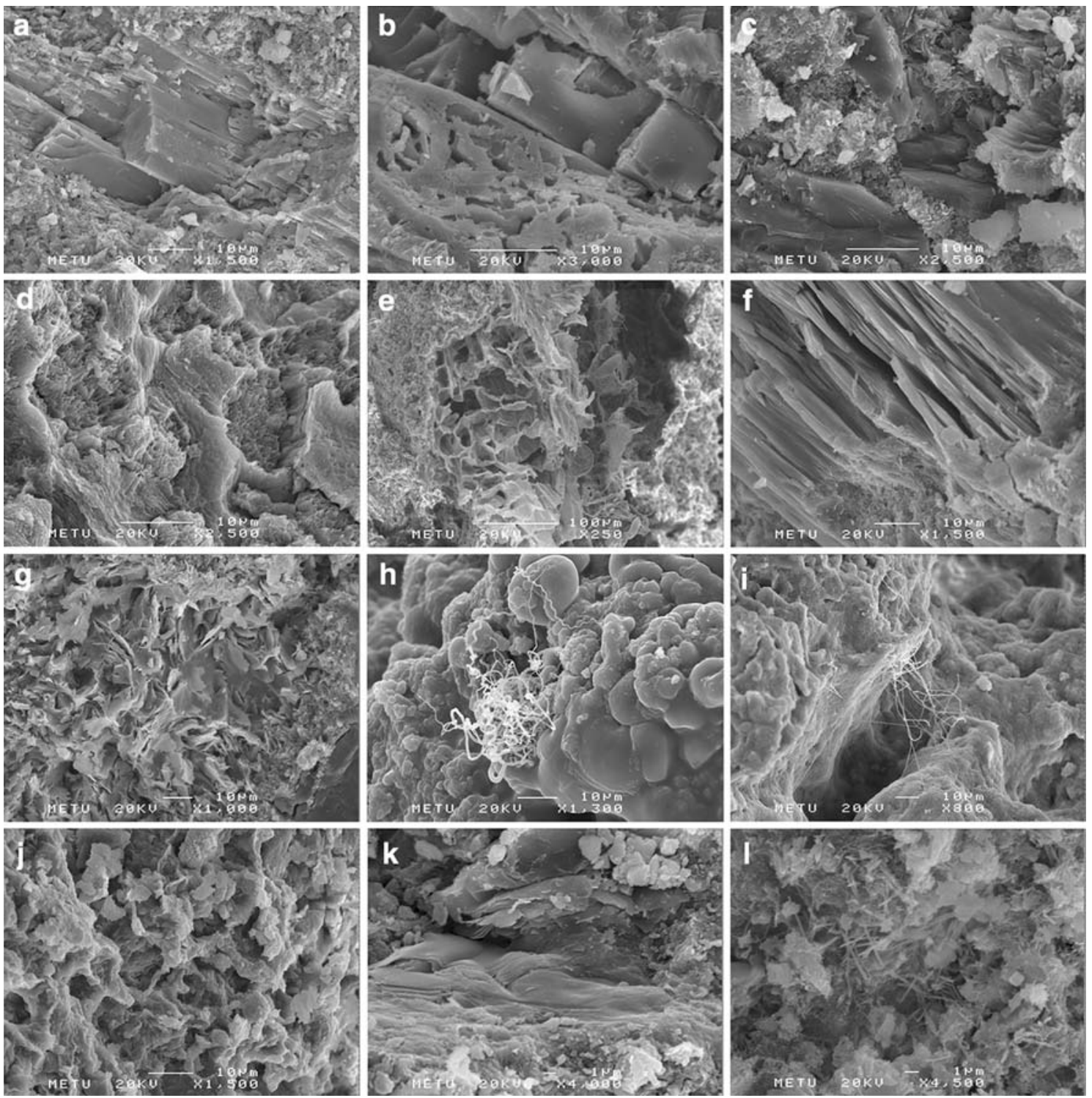

Fig. 4 SEM images of (a) feldspar blocks surrounded by spongy alteration products; (b) dissolved feldspar blocks; (c) spongy cornflake-type smectite-illite, developed mainly on and between dissolved and irregular feldspar grains; (d) development of authigenic smectiteillite in dissolution voids; (e) development of authigenic smectite flex in microfractures; (f) sub-parallel thick plates developed by degradation of feldspar and partly surrounded by alteration products; (g)

rocks. The rocks are mainly plotted in the andesite field in the $\mathrm{Zr} / \mathrm{TiO}_{2}$ versus $\mathrm{Nb} / \mathrm{Y}$ diagram (Fig. 6a). The general geochemical character of the samples is shown in the $\mathrm{P}_{2} \mathrm{O}_{5}$ versus $\mathrm{Zr}$ and AFM diagrams (Fig. 6b, c). The analyzed rocks are subalkaline and exhibit a calc-alkaline trend indicating oxidizing conditions with no early iron enrichment. Based on the Leat et al. (1986) magma discrimination series, which depends on absolute $\mathrm{Zr}$ abundances, the rocks have subalkaline affinity and $<500 \mathrm{ppm} Z \mathrm{Zr}$. Wholerock $\mathrm{Zr}$ contents of the analyzed samples ranged from 113 to $270 \mathrm{ppm}$. In general, low $\mathrm{Zr}$ may represent primitive development of irregular kaolinite plates sub-parallel to the veins and cracks axes; (h) growth of interwoven, long mordenite fibers on subrounded aggregates, representing microorganisms; (i) development of interwoven, long mordenite fibers between microfracture walls; (j) calcified filaments in soil profiles; (k) oriented flexible continuous layers resembling biotite; (l) needle-type chrysotile crystals in the concrete buildings

rocks, especially sample ZG6, which may be the most primitive, representing the highest degree of melting as it also has relatively high $\mathrm{Ni}$ and $\mathrm{Cr}$ contents.

On the basis of their petrography and geochemistry. andesites show two main groups which both have subalkaline character. The samples (ZG6, ZG39a, ZG39b, and ZG39f) from the Dinlence Formation have $\mathrm{SiO}_{2}$ content between 54.58 and $57.67 \mathrm{wt} \%$ (except ZG39b with $33.76 \mathrm{wt} \% \mathrm{SiO}_{2}$ because of the alteration effect) whereas the samples (ZG27, ZG38a, ZG38b, ZG38c, and ZG40f) from the Kazpinar Formation have higher $\mathrm{SiO}_{2}$ contents of 
Fig. 5 DTA-TG curves for (a) smectite sample ZG34b and (b) kaolinite sample ZG39c

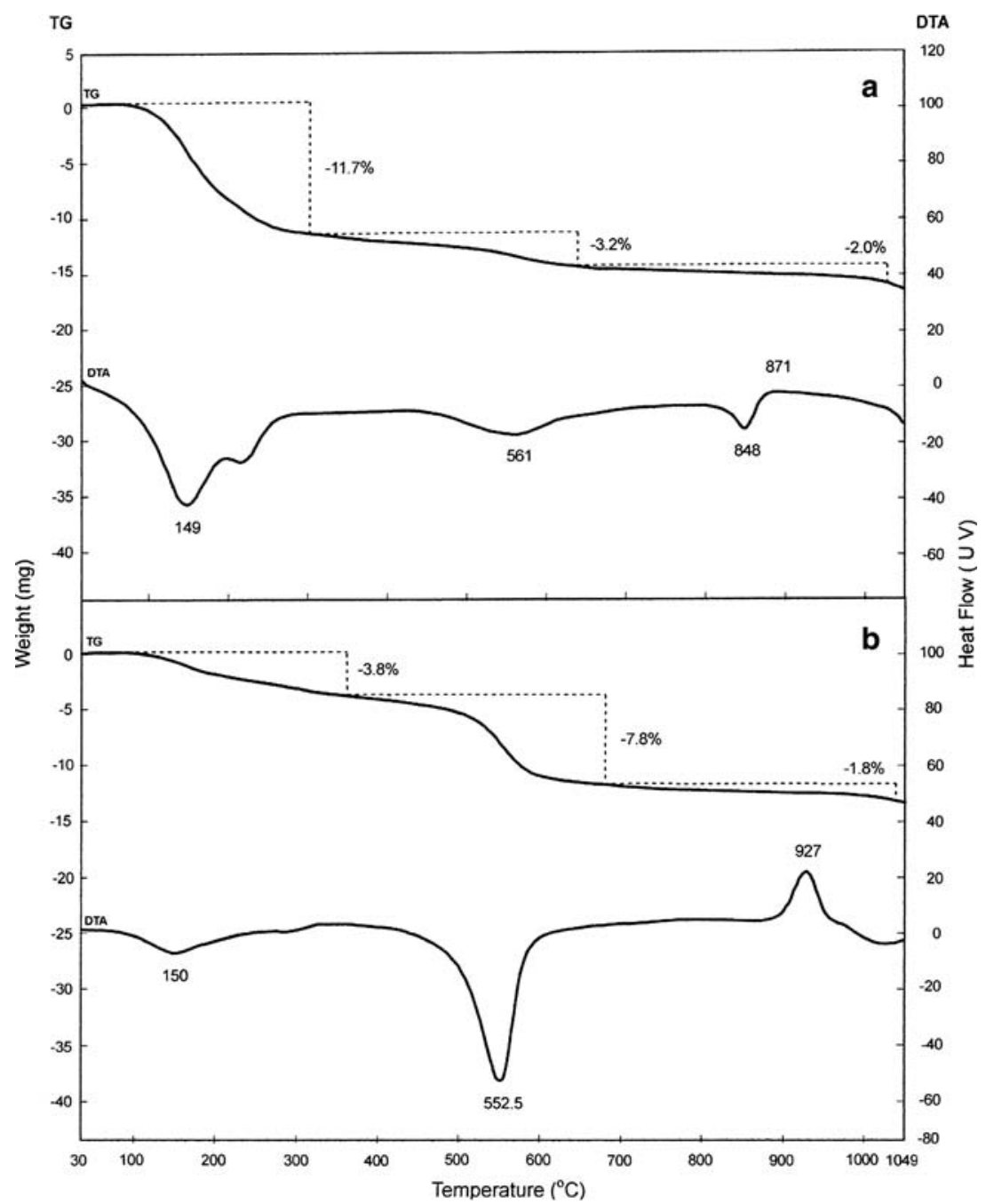

between 61.21 and $64.71 \mathrm{wt} \%$. Tuffs from the Gökçetepe Formation (ZG11 and ZG17) have $\mathrm{SiO}_{2}$ contents of 49.21 and $51.12 \mathrm{wt} \%$, respectively. Regarding the major element variation of the samples on the Harker diagrams, there are negative trends for $\mathrm{TiO}_{2}, \mathrm{Na}_{2} \mathrm{O}, \mathrm{CaO}, \mathrm{Fe}_{2} \mathrm{O}_{3}{ }^{*}$, and $\mathrm{K}_{2} \mathrm{O}$ versus $\mathrm{SiO}_{2}$ diagrams, and positive trends for $\mathrm{Al}_{2} \mathrm{O}_{3}$ versus $\mathrm{SiO}_{2}$ diagrams. The increase in $\mathrm{TiO}_{2}$ with respect to $\mathrm{SiO}_{2}$ may be due to fractionating Ti-bearing phases, like titanomagnetite, hornblende, and biotite.

The effects of alteration cause the scatter in the variation diagrams. Samples display an increase in $\mathrm{MnO}, \mathrm{Fe}_{2} \mathrm{O}_{3}{ }^{*}, \mathrm{Sr}$, and $\mathrm{SiO}_{2}$, though only slightly in $\mathrm{MgO}$ and $\mathrm{CaO}$, while elements like $\mathrm{Al}_{2} \mathrm{O}_{3}, \mathrm{~K}_{2} \mathrm{O}$, and $\mathrm{Rb}$, correlate negatively with LOI. There is no particular change in $\mathrm{Na}_{2} \mathrm{O}$. Since $\mathrm{SiO}_{2}$ is variably mobile, trace elements were plotted against $\mathrm{Zr}$ as a differentiation index in order to understand if there were any distinct chemical suites within the samples. $\mathrm{Zr}$ versus $\mathrm{Nb}$, $\mathrm{Y}$, and Th plots, as well as La versus $\mathrm{Nb}$, and $\mathrm{TiO}_{2}$ versus $\mathrm{Zr}$ and $\mathrm{Th}$ (Fig. 7) distinguish the samples from the Dinlence and Kazpınar formations.
MORB-normalized trace element diagrams have a common pattern for all samples, showing enrichment in large ion lithophile elements (LILE) relative to high field strength elements (HFSE) (Fig. 8a). The sample ZG38b shows strongly depleted $\mathrm{Sr}$, which is a compatible element with plagioclase, and sample ZG40a shows Rb depletion. In general, samples ZG11, ZG17, and ZG40a have a more depleted pattern relative to the others. Although there is a general $\mathrm{Nb}$-depletion anomaly, a trough at $\mathrm{Th}$ and $\mathrm{Rb}$ together with $\mathrm{Nb}$ and $\mathrm{Ta}$, which suggests contamination of magma by lower continental crustal rocks, can be seen. The Kazpınar and Dinlence formations show the groupings that have a slightly different MORB-normalized pattern in which the Kazpınar Formation samples show a more enriched LILE pattern than the Dinlence Formation samples. This feature is also observed in chondrite-normalized diagrams (Fig. 8b), although all the groups have a common pattern. Chondritenormalized diagrams display a similar pattern characterized by enrichment in LIL elements relative to HFS elements, indicating continental crust involvement in their genesis. 
Table 2 Representative whole-rock major trace and REE chemical analyses of andesites, tuffs, sandstones, and soil samples from the Gökçeler Village area. $\mathrm{Fe}_{2} \mathrm{O}_{3}$ is total iron

\begin{tabular}{|c|c|c|c|c|c|c|c|c|c|c|c|}
\hline (wt\%) & $\begin{array}{l}\text { Andesite } \\
\text { ZG6 }\end{array}$ & $\begin{array}{l}\text { Andesite } \\
\text { ZG27 }\end{array}$ & $\begin{array}{l}\text { Andesite } \\
\text { ZG38a }\end{array}$ & $\begin{array}{l}\text { Andesite } \\
\text { ZG38b }\end{array}$ & $\begin{array}{l}\text { Andesite } \\
\text { ZG38c }\end{array}$ & $\begin{array}{l}\text { Andesite } \\
\text { ZG39a }\end{array}$ & $\begin{array}{l}\text { Andesite } \\
\text { ZG39b }\end{array}$ & $\begin{array}{l}\text { Lithic tuff } \\
\text { ZG39f }\end{array}$ & $\begin{array}{l}\text { Vitrified tuff } \\
\text { ZG40a }\end{array}$ & $\begin{array}{l}\text { Tuff } \\
\text { ZG11 }\end{array}$ & $\begin{array}{l}\text { Tuff } \\
\text { ZG17 }\end{array}$ \\
\hline $\mathrm{SiO}_{2}$ & 57.67 & 61.53 & 64.71 & 63.23 & 61.21 & 56.84 & 33.76 & 54.58 & 63.74 & 49.21 & 51.12 \\
\hline $\mathrm{Al}_{2} \mathrm{O}_{3}$ & 16.88 & 18.03 & 17.71 & 18.21 & 19.67 & 17.22 & 28.62 & 15.56 & 13.28 & 17.63 & 15.38 \\
\hline $\mathrm{Fe}_{2} \mathrm{O}_{3}$ & 7.62 & 4.64 & 4.34 & 4.60 & 5.39 & 7.68 & 13.32 & 7.05 & 4.05 & 7.87 & 8.81 \\
\hline $\mathrm{MgO}$ & 2.70 & 1.05 & 0.96 & 0.93 & 0.89 & 2.48 & 1.56 & 3.52 & 1.15 & 4.51 & 5.11 \\
\hline $\mathrm{CaO}$ & 6.06 & 2.11 & 1.29 & 0.92 & 0.32 & 3.29 & 1.25 & 6.06 & 4.36 & 5.81 & 6.94 \\
\hline $\mathrm{Na}_{2} \mathrm{O}$ & 4.96 & 4.14 & 3.85 & 3.66 & 1.84 & 3.60 & 0.41 & 4.12 & 1.30 & 4.08 & 4.08 \\
\hline $\mathrm{K}_{2} \mathrm{O}$ & 1.50 & 6.89 & 6.69 & 6.71 & 5.96 & 2.32 & 1.38 & 1.37 & 0.48 & 1.12 & 0.78 \\
\hline $\mathrm{TiO}_{2}$ & 0.85 & 0.52 & 0.52 & 0.55 & 0.65 & 0.89 & 1.36 & 0.83 & 0.50 & 0.68 & 0.77 \\
\hline $\mathrm{P}_{2} \mathrm{O}_{5}$ & 0.25 & 0.23 & 0.20 & 0.15 & 0.07 & 0.29 & 0.87 & 0.20 & 0.11 & 0.12 & 0.14 \\
\hline $\mathrm{MnO}$ & 0.108 & 0.153 & 0.113 & 0.097 & 0.123 & 0.124 & 0.119 & 0.139 & 0.126 & 0.225 & 0.171 \\
\hline LOI & 1.8 & 1.8 & 2.1 & 2.3 & 5.7 & 5.9 & 17.3 & 6.4 & 12.2 & 8.9 & 7.0 \\
\hline \multicolumn{12}{|c|}{ Total (ppm) } \\
\hline $\mathrm{Ba}$ & 270 & 1258 & 1173 & 1180 & 1101 & 628 & 582 & 340 & 423 & 531 & 197 \\
\hline Co & 18 & 5 & 4 & 5 & 7 & 17 & 35 & 22 & 4 & 18 & 22 \\
\hline $\mathrm{Cr}$ & 254 & 128 & 147 & 114 & 67 & 98 & 121 & 114 & 55 & 69 & 160 \\
\hline $\mathrm{Cu}$ & 52 & 52 & 53 & 17 & 23 & 44 & 58 & 42 & 26 & 115 & 96 \\
\hline $\mathrm{Li}$ & 14 & 7 & 9 & 12 & 13 & 20 & 34 & 16 & 13 & 44 & 24 \\
\hline $\mathrm{Ni}$ & 37 & 10 & 10 & 10 & 13 & 17 & 31 & 21 & 7 & 20 & 25 \\
\hline $\mathrm{Sc}$ & 19 & 7 & 7 & 7 & 9 & 17 & 37 & 18 & 13 & 22 & 30 \\
\hline $\mathrm{Sr}$ & 423 & 358 & 240 & 217 & 121 & 449 & 31 & 597 & 1364 & 1096 & 541 \\
\hline V & 161 & 78 & 70 & 74 & 92 & 122 & 156 & 146 & 44 & 192 & 247 \\
\hline $\mathrm{Zn}$ & 64 & 74 & 47 & 56 & 57 & 71 & 141 & 70 & 65 & 75 & 73 \\
\hline $\mathrm{Zr}$ & 113 & 123 & 124 & 133 & 149 & 145 & 270 & 123 & 120 & 63 & 73 \\
\hline $\mathrm{Pb}$ & 19 & 23 & 21 & 19 & 24 & 19 & 35 & 15 & 15 & 16 & 13 \\
\hline $\mathrm{U}$ & 1.06 & 2.69 & 3.22 & 3.49 & 3.91 & 0.99 & 2.82 & 1.90 & 0.83 & 0.56 & 0.55 \\
\hline Th & 4.07 & 9.62 & 9.61 & 10.50 & 10.88 & 4.60 & 8.39 & 4.46 & 3.05 & 2.45 & 2.39 \\
\hline $\mathrm{Rb}$ & 41 & 157 & 192 & 174 & 173 & 68 & 36 & 32 & 8 & 16 & 15 \\
\hline $\mathrm{Nb}$ & 12.3 & 5.6 & 5.6 & 5.9 & 8.1 & 11.3 & 22.2 & 11.8 & 3.5 & 2.6 & 2.6 \\
\hline $\mathrm{Cs}$ & 0.81 & 0.86 & 0.57 & 0.46 & 1.46 & 1.07 & 1.17 & 0.89 & 0.33 & 2.39 & 0.30 \\
\hline $\mathrm{Hf}$ & 3.18 & 3.32 & 3.10 & 3.49 & 3.90 & 3.50 & 5.95 & 3.22 & 3.61 & 2.02 & 1.99 \\
\hline $\mathrm{Ta}$ & 0.73 & 0.35 & 0.33 & 0.35 & 0.53 & 0.68 & 1.25 & 0.70 & 0.24 & 0.18 & 0.16 \\
\hline $\mathrm{Tl}$ & 0.1 & 1.1 & 0.9 & 0.8 & 0.9 & 0.7 & 0.3 & 0.3 & 0.1 & 0.1 & 0.2 \\
\hline Y & 23 & 27 & 30 & 25 & 23 & 26 & 25 & 24 & 41 & 14 & 20 \\
\hline $\mathrm{La}$ & 19.7 & 24.1 & 28.6 & 26.9 & 24 & 28.3 & 47.3 & 18.8 & 12.0 & 11.9 & 9.8 \\
\hline $\mathrm{Ce}$ & 36.2 & 44.6 & 39.6 & 28.9 & 47.8 & 39.9 & 52.1 & 34.5 & 25.4 & 24.0 & 20.0 \\
\hline $\operatorname{Pr}$ & 4.2 & 5.5 & 6.6 & 6.9 & 5.4 & 5.3 & 7.3 & 3.9 & 3.7 & 3.0 & 2.7 \\
\hline $\mathrm{Nd}$ & 18.4 & 23.8 & 28.3 & 28.5 & 22.2 & 22.0 & 27.2 & 16.7 & 17.5 & 14.2 & 13.0 \\
\hline $\mathrm{Sm}$ & 4.01 & 5.08 & 6.01 & 6.14 & 4.78 & 4.55 & 5.99 & 3.68 & 4.89 & 2.89 & 3.27 \\
\hline $\mathrm{Eu}$ & 1.16 & 1.30 & 1.43 & 1.46 & 1.17 & 1.27 & 1.64 & 1.05 & 1.13 & 0.83 & 0.93 \\
\hline $\mathrm{Gd}$ & 3.44 & 4.06 & 4.67 & 4.45 & 3.55 & 3.88 & 4.60 & 3.29 & 4.51 & 2.23 & 2.80 \\
\hline Dy & 3.28 & 3.78 & 4.28 & 4.01 & 3.20 & 3.89 & 5.15 & 3.34 & 5.31 & 2.09 & 2.93 \\
\hline Но & 0.69 & 0.78 & 0.84 & 0.80 & 0.68 & 0.77 & 1.01 & 0.71 & 1.18 & 0.42 & 0.66 \\
\hline $\mathrm{Er}$ & 1.85 & 2.14 & 2.28 & 2.06 & 1.92 & 2.09 & 2.69 & 1.89 & 3.30 & 1.15 & 1.62 \\
\hline $\mathrm{Yb}$ & 1.93 & 2.65 & 2.55 & 2.49 & 2.29 & 2.41 & 3.50 & 2.16 & 3.82 & 1.29 & 1.88 \\
\hline $\mathrm{Lu}$ & 0.32 & 0.43 & 0.43 & 0.41 & 0.39 & 0.41 & 0.55 & 0.35 & 0.60 & 0.20 & 0.31 \\
\hline Mo & 7.0 & 3.4 & 3.5 & 2.8 & 1.6 & 1.4 & 0.8 & 1.9 & 1.1 & 1.0 & 2.0 \\
\hline $\mathrm{Sn}$ & 1.1 & 1.0 & 1.4 & 1.1 & 1.2 & 0.9 & 1.4 & 1.0 & 1.3 & 1.0 & 1.1 \\
\hline W & 0.3 & 1.4 & 0.3 & 1.2 & 1.1 & 0.2 & 0.7 & 4.2 & 0.4 & 0.9 & 0.4 \\
\hline
\end{tabular}


Table 2 continued

\begin{tabular}{|c|c|c|c|c|c|c|c|c|c|c|c|}
\hline$(\mathrm{wt} \%)$ & $\begin{array}{l}\text { Soil } \\
\text { ZG8 }\end{array}$ & $\begin{array}{l}\text { Soil } \\
\text { ZG24 }\end{array}$ & $\begin{array}{l}\text { Soil } \\
\text { ZG28 }\end{array}$ & $\begin{array}{l}\text { Soil } \\
\text { ZG39c }\end{array}$ & $\begin{array}{l}\text { Soil } \\
\text { ZG39d }\end{array}$ & $\begin{array}{l}\text { Soil } \\
\text { ZG40b }\end{array}$ & $\begin{array}{l}\text { Sandstone } \\
\text { ZG36b }\end{array}$ & $\begin{array}{l}\text { Subarkose } \\
\text { ZG41a }\end{array}$ & $\begin{array}{l}\text { Micrite-siltstone } \\
\text { ZG25 }\end{array}$ & $\begin{array}{l}\text { Lithic arkose } \\
\text { ZG37a }\end{array}$ & $\begin{array}{l}\text { Sandstone } \\
\text { ZG34b }\end{array}$ \\
\hline $\mathrm{SiO}_{2}$ & 55.46 & 45.89 & 53.66 & 40.76 & 48.03 & 59.64 & 53.69 & 60.88 & 29.29 & 49.90 & 51.64 \\
\hline $\mathrm{Al}_{2} \mathrm{O}_{3}$ & 17.74 & 15.29 & 17.21 & 28.34 & 23.16 & 14.81 & 15.59 & 9.95 & 5.79 & 14.51 & 16.07 \\
\hline $\mathrm{Fe}_{2} \mathrm{O}_{3}$ & 7.68 & 5.49 & 6.44 & 10.99 & 11.72 & 5.30 & 3.94 & 3.58 & 3.38 & 5.99 & 4.69 \\
\hline $\mathrm{MgO}$ & 1.96 & 2.92 & 2.01 & 1.03 & 1.03 & 1.69 & 2.72 & 1.67 & 1.00 & 1.90 & 4.08 \\
\hline $\mathrm{CaO}$ & 2.39 & 10.50 & 3.10 & 0.31 & 0.34 & 3.87 & 5.08 & 9.06 & 30.77 & 9.83 & 3.58 \\
\hline $\mathrm{Na}_{2} \mathrm{O}$ & 1.63 & 089 & 4.63 & 0.02 & 0.15 & 1.14 & 0.48 & 3.62 & 0.68 & 1.38 & 1.11 \\
\hline $\mathrm{K}_{2} \mathrm{O}$ & 1.92 & 0.43 & 1.12 & 0.19 & 1.03 & 0.52 & 0.58 & 0.48 & 0.74 & 2.05 & 0.64 \\
\hline $\mathrm{TiO}_{2}$ & 0.71 & 0.58 & 0.66 & 1.08 & 1.43 & 0.58 & 0.46 & 0.38 & 0.20 & 0.57 & 0.48 \\
\hline $\mathrm{P}_{2} \mathrm{O}_{5}$ & 0.06 & 0.27 & 0.16 & 0.14 & 0.10 & 0.10 & 0.15 & 0.11 & 0.12 & 0.10 & 0.19 \\
\hline $\mathrm{MnO}$ & 0.248 & 0.274 & 0.119 & 0.076 & 0.394 & 0.213 & 0.180 & 0.124 & 0.452 & 0.070 & 0.029 \\
\hline LOI & 11.4 & 18.6 & 12.2 & 17.2 & 13.9 & 13.6 & 18.5 & 10.7 & 27.2 & 15.4 & 18.1 \\
\hline \multicolumn{12}{|c|}{ Total (ppm) } \\
\hline $\mathrm{Ba}$ & 916 & 489 & 201 & 254 & 242 & 676 & 1115 & 108 & 320 & 850 & 473 \\
\hline $\mathrm{Co}$ & 17 & 20 & 13 & 14 & 36 & 7 & 6 & 8 & 5 & 8 & 4 \\
\hline $\mathrm{Cr}$ & 87 & 73 & 109 & 38 & 101 & 51 & 65 & 299 & 37 & 106 & 38 \\
\hline $\mathrm{Cu}$ & 66 & 162 & 94 & 45 & 48 & 37 & 49 & 47 & 36 & 36 & 21 \\
\hline $\mathrm{Li}$ & 33 & 37 & 17 & 36 & 37 & 14 & 61 & 25 & 13 & 31 & 190 \\
\hline $\mathrm{Ni}$ & 26 & 38 & 15 & 17 & 44 & 9 & 15 & 30 & 26 & 24 & 7 \\
\hline $\mathrm{Sc}$ & 17 & 14 & 17 & 28 & 22 & 17 & 11 & 13 & 6 & 12 & 6 \\
\hline $\mathrm{Sr}$ & 408 & 631 & 413 & 7 & 34 & 1015 & 1795 & 110 & 596 & 768 & 557 \\
\hline V & 147 & 144 & 175 & 189 & 224 & 70 & 76 & 126 & 52 & 103 & 75 \\
\hline $\mathrm{Zn}$ & 81 & 88 & 64 & 77 & 110 & 71 & 56 & 38 & 42 & 67 & 63 \\
\hline $\mathrm{Zr}$ & 120 & 97 & 71 & 218 & 275 & 124 & 226 & 145 & 43 & 134 & 146 \\
\hline $\mathrm{Pb}$ & 31 & 77 & 16 & 30 & 36 & 15 & 30 & 13 & 40 & 16 & 26 \\
\hline $\mathrm{U}$ & 1.38 & 0.80 & 0.75 & 2.22 & 3.31 & 0.91 & 4.24 & 1.17 & 0.38 & 1.37 & 2.00 \\
\hline $\mathrm{Th}$ & 7.40 & 4.94 & 2.74 & 8.58 & 12.73 & 3.35 & 14.78 & 3.30 & 2.62 & 7.39 & 11.08 \\
\hline $\mathrm{Rb}$ & 72 & 16 & 24 & 17 & 71 & 12 & 12 & 15 & 33 & 59 & 20 \\
\hline $\mathrm{Nb}$ & 10.8 & 4.0 & 3.0 & 18.1 & 23.3 & 3.7 & 9.5 & 3.8 & 2.3 & 10.1 & 9.6 \\
\hline $\mathrm{Cs}$ & 3.58 & 1.36 & 1.72 & 1.30 & 4.35 & 0.61 & 0.41 & 1.15 & 1.66 & 3.32 & 3.16 \\
\hline $\mathrm{Hf}$ & 3.42 & 2.67 & 2.04 & 5.27 & 6.95 & 3.77 & 5.77 & 3.88 & 0.98 & 3.43 & 3.43 \\
\hline $\mathrm{Ta}$ & 0.67 & 0.28 & 0.20 & 1.18 & 1.48 & 0.25 & 0.64 & 0.26 & 0.16 & 0.67 & 0.69 \\
\hline $\mathrm{Tl}$ & 0.6 & 0.3 & 0.3 & 0.3 & 0.8 & 0.2 & 0.4 & 0.2 & 0.5 & 0.8 & 0.2 \\
\hline $\mathrm{Y}$ & 33 & 18 & 17 & 75 & 23 & 41 & 31 & 15 & 19 & 16 & 24 \\
\hline $\mathrm{La}$ & 32.6 & 10.1 & 10.6 & 65.5 & 28.4 & 13.2 & 26.3 & 12.9 & 16.1 & 16.6 & 23.6 \\
\hline $\mathrm{Ce}$ & 56.3 & 22.1 & 21.8 & 103.4 & 80.1 & 27.7 & 57.3 & 25.4 & 22.5 & 32.7 & 49.5 \\
\hline $\operatorname{Pr}$ & 7.1 & 3.0 & 2.9 & 15.6 & 5.1 & 4.0 & 6.9 & 3.1 & 3.0 & 3.9 & 5.7 \\
\hline $\mathrm{Nd}$ & 30.7 & 14.0 & 13.1 & 66.4 & 19.9 & 18.9 & 28.5 & 13.0 & 12.9 & 16.2 & 24.0 \\
\hline $\mathrm{Sm}$ & 6.42 & 3.42 & 3.20 & 13.27 & 3.62 & 4.98 & 6.01 & 2.62 & 2.58 & 3.56 & 4.86 \\
\hline $\mathrm{Eu}$ & 1.56 & 0.96 & 0.90 & 3.26 & 0.78 & 1.14 & 0.93 & 0.59 & 0.63 & 0.86 & 1.24 \\
\hline $\mathrm{Gd}$ & 5.13 & 2.88 & 2.55 & 11.00 & 3.20 & 4.47 & 4.46 & 2.23 & 2.29 & 2.80 & 3.73 \\
\hline Dy & 4.85 & 2.89 & 2.47 & 10.37 & 3.07 & 5.51 & 4.52 & 1.96 & 2.30 & 2.64 & 3.43 \\
\hline Ho & 1.00 & 0.59 & 0.53 & 2.21 & 0.65 & 1.17 & 0.89 & 0.44 & 0.49 & 0.54 & 0.72 \\
\hline $\mathrm{Er}$ & 2.62 & 1.60 & 1.34 & 5.87 & 1.81 & 3.34 & 2.50 & 1.15 & 1.30 & 1.45 & 1.92 \\
\hline $\mathrm{Yb}$ & 2.93 & 1.69 & 1.50 & 6.21 & 2.25 & 3.84 & 2.79 & 1.29 & 1.45 & 1.83 & 2.35 \\
\hline $\mathrm{Lu}$ & 0.47 & 0.27 & 0.25 & 0.97 & 0.38 & 0.63 & 0.46 & 0.21 & 0.23 & 0.30 & 0.40 \\
\hline Mo & 1.4 & 1.3 & 1.8 & 0.1 & 1.1 & 0.7 & 0.9 & 4.8 & 0.2 & 1.4 & 0.2 \\
\hline $\mathrm{Sn}$ & 1.5 & 1.3 & 1.3 & 1.5 & 2.1 & 1.1 & 2.1 & 0.7 & 1.2 & 1.1 & 3.3 \\
\hline W & 1.0 & 0.2 & 0.7 & 0.6 & 1.9 & 0.4 & 0.2 & 0.3 & 0.9 & 0.6 & 2.0 \\
\hline
\end{tabular}



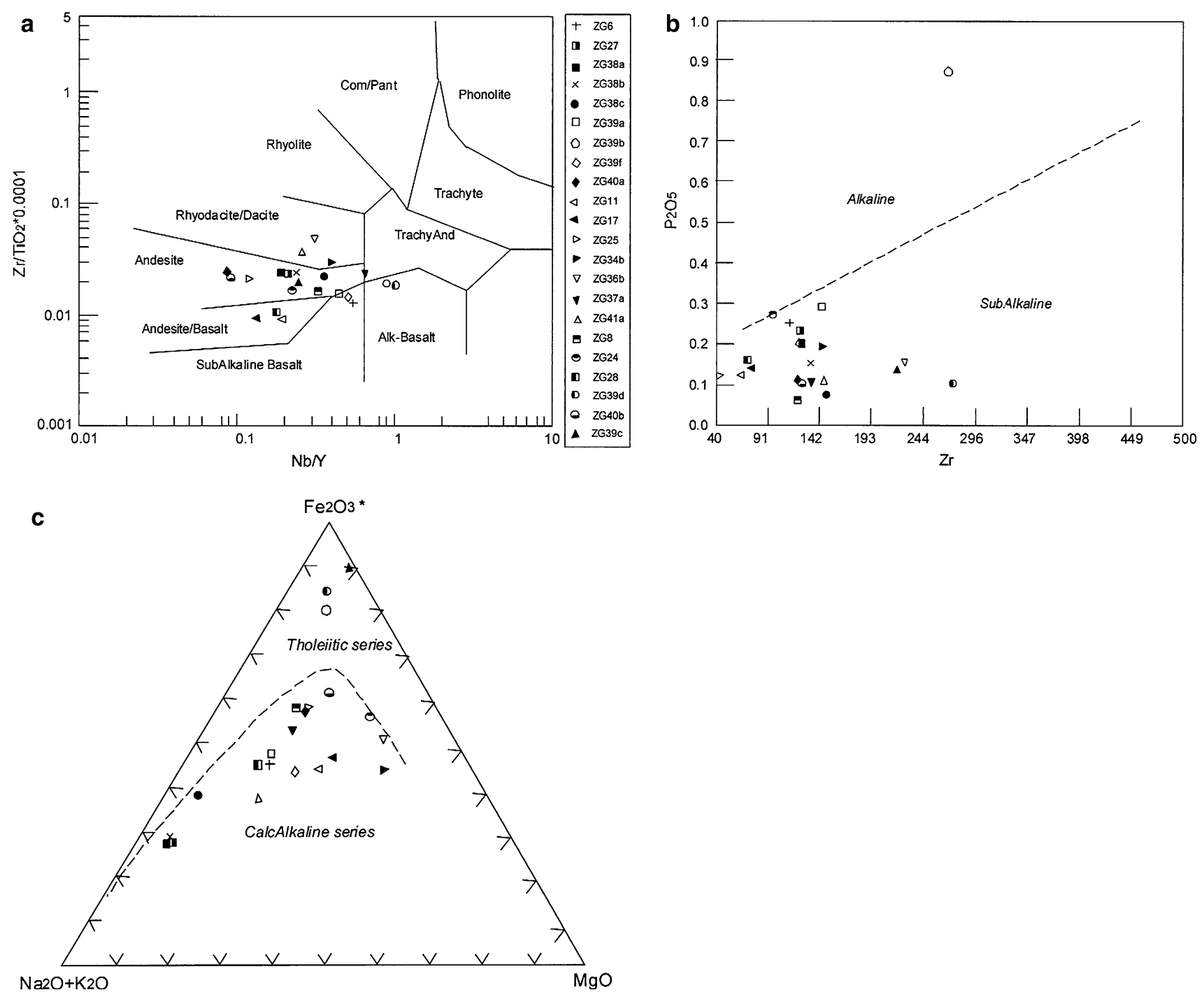

Fig. 6 a $\mathrm{Zr} / \mathrm{TiO}_{2}$ versus $\mathrm{Nb} / \mathrm{Y}$ diagram (after Winchester and Floyd 1977). b $\mathrm{P}_{2} \mathrm{O}_{5}$ versus $\mathrm{Zr}$ diagram (after Floyd and Winchester 1975). c AFM diagram (after Kuno 1968) of the analyzed samples

The samples have calc-alkaline character in the Ti-Zr$\mathrm{Y}$ (except ZG39b and ZG40a) and Ti-Zr discrimination diagrams (Fig. 9a, b). In the 2Nb-Zr/4-Y diagram (Fig. 9c), samples are seen in the volcanic arc basalt field. Additionally, discrimination diagrams based on the immobile HFS elements Th-Hf-Ta samples plot in the volcanic arc basalts on the Hf/3-Th-Ta diagram (Fig. 9d). This diagram is subdivided into the island-arc tholeiites (primitive arc tholeiites) with an $\mathrm{Hf} / \mathrm{Th}$ ratio $>3.0$, and calc-alkaline basalts with an $\mathrm{Hf} / \mathrm{Th}$ ratio $<3.0$. Zonguldak samples have an $\mathrm{Hf} / \mathrm{Ta}$ ratio $<3.0$, indicating calc-alkaline character.

\section{Alteration geochemistry}

The geochemical correlation products with partly altered and fresh samples reveal that different contents of $\mathrm{SiO}_{2}, \mathrm{Al}_{2} \mathrm{O}_{3}$, $\mathrm{Fe}_{2} \mathrm{O}_{3}, \mathrm{MgO}, \mathrm{CaO}, \mathrm{Na}_{2} \mathrm{O}$, and $\mathrm{K}_{2} \mathrm{O}$, and loss on ignition are consistent with the mineralogical compositions (Tables 1 and 2). The $\mathrm{SiO}_{2}$ values are attributed to the presence of smectite, chlorite, kaolinite, analcime, feldspar, quartz, and opal-CT. The high $\mathrm{Al}_{2} \mathrm{O}_{3}$ values are mainly from smectite, kaolinite, and analcime, and partially from chlorite, illite, and feldspar. As the $\mathrm{Fe}_{2} \mathrm{O}_{3}$-content in the clay size fraction increased in comparison to the fresh host samples, indicating that $\mathrm{Fe}_{2} \mathrm{O}_{3}$ appears to be bound with alteration products, such as smectite and kaolinite, because no evidence of other ironbearing phases, except traces of hematite and illite, was detected by XRD in some samples and this makes it a slightly ferriferous mineral. This may reveal that $\mathrm{Fe}$ substituted $\mathrm{Al}$ in the octahedral of smectite- and kaolinite-type clay minerals during physico-chemical alteration processes. The amount of $\mathrm{Al}_{2} \mathrm{O}_{3}+\mathrm{Fe}_{2} \mathrm{O}_{3}$ increased and $\mathrm{Na}_{2} \mathrm{O}+\mathrm{K}_{2} \mathrm{O}+\mathrm{CaO}$ decreased upward of the soil profiles where the alteration degrees increased gradually within approximately $3 \mathrm{~m}$. 
Fig. 7 Diagrams of the analyzed samples. a $\mathrm{Nb}$ versus $\mathrm{Zr}$ diagram. b $\mathrm{Y}$ versus $\mathrm{Zr}$ diagram. $\mathbf{c}$ Th versus $\mathrm{Zr}$ diagram. d Th versus $\mathrm{TiO}_{2}$ diagram. e $\mathrm{Zr}$ versus $\mathrm{TiO}_{2}$ diagram. $\mathbf{f} \mathrm{Nb}$ versus $\mathrm{La}$ diagram (Symbols are the same as those in Fig. 6a)
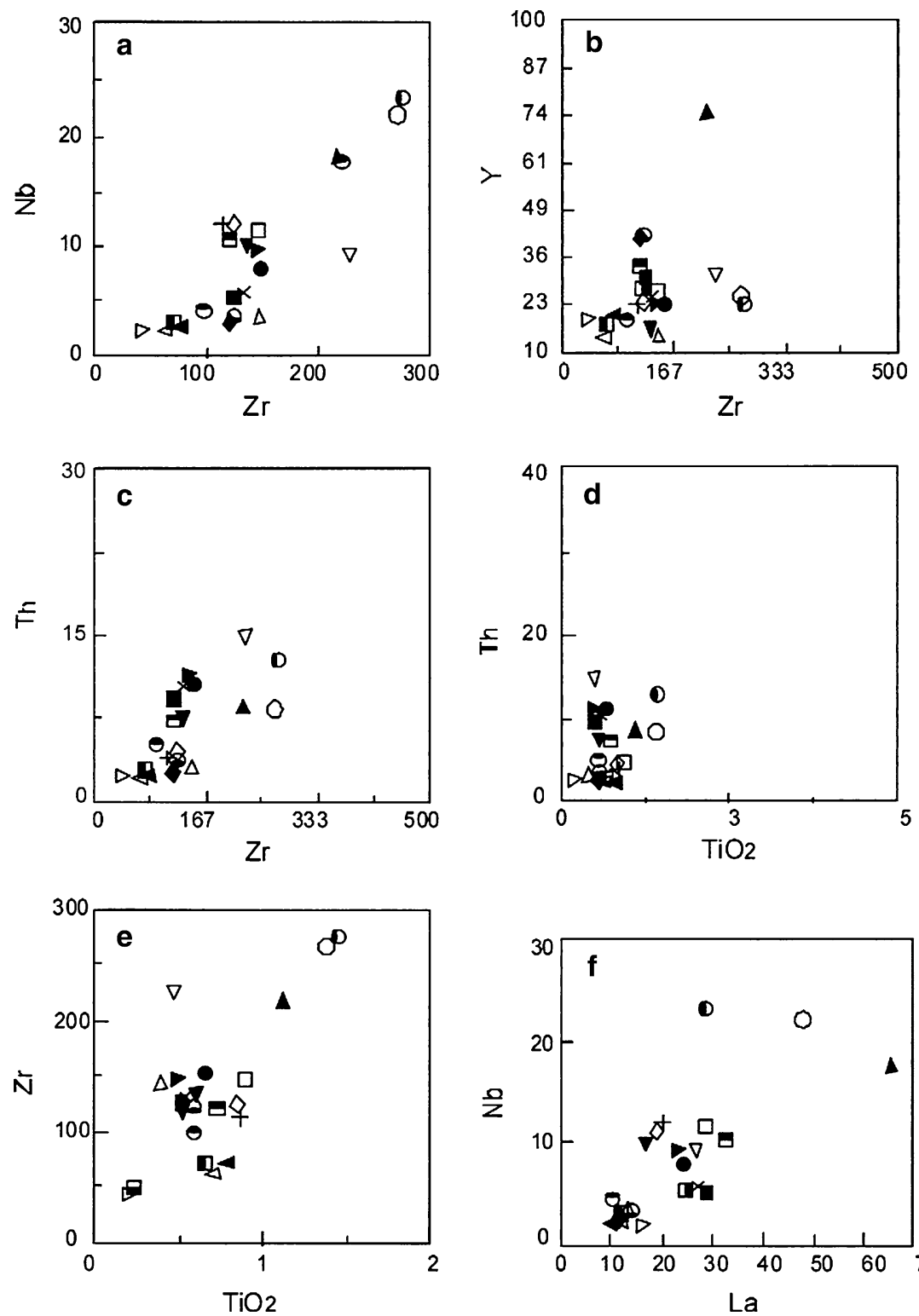

The gain and loss of the elements is possibly due to the difference of element mobility and the leaching of mobile elements downward following degradation of the minerals, as well as the release of the elements similar to the case in samples ZG38a, ZG38b, ZG38c, ZG40a, and ZG40b, and especially samples ZG39a, ZG39b, ZG39c, ZG39d, ZG39e, and ZG39f in which $\mathrm{Na}_{2} \mathrm{O}$ values have a positive correlation with analcime and feldspar. $\mathrm{K}_{2} \mathrm{O}$ content is due to the presence of illite. The small $\mathrm{MgO}$ values are possibly representative of smectite- and chlorite-type alteration products rather than other $\mathrm{Mg}$-bearing minerals, such as dolomite, which are either absent or occurred as accessories in some places.

$\mathrm{Zr}, \mathrm{U}, \mathrm{Th}, \mathrm{Nb}, \mathrm{Hf}, \mathrm{Li}, \mathrm{Zn}, \mathrm{V}, \mathrm{Co}, \mathrm{Cs}$, and $\mathrm{Ta}$ are immobile and positively enhanced with increased alteration processes of the volcanic units, whereas $\mathrm{Sr}$, in relation to soluble $\mathrm{Na}$ and $\mathrm{Ca}$, is mobile and leached downward from the soil towards the host rock. Decreased $\mathrm{Sr}$ in relation to $\mathrm{Ca}$ with increased alteration may indicate the alteration developed in a terrigenous environment. On the other hand, $\mathrm{Ba}$ and $\mathrm{Rb}$, in relation to $\mathrm{K}$, exhibit a moderately mobile character. Therefore, $\mathrm{Ca}, \mathrm{Na}, \mathrm{K}$, and $\mathrm{Mg}$ content decrease, whereas $\mathrm{Zr}, \mathrm{U}$, Th, Nb, Hf, $\mathrm{Li}, \mathrm{Zn}, \mathrm{V}$, Co, Cs, and Ta, and partially $\mathrm{Ba}$ and $\mathrm{Rb}$ content increase upward of the alteration profile, where the alteration degree increased gradually under the influence of vadose water.

\section{Genetical results}

In the field study, various types of cancers, such as osteosarcoma, pancreatic cancer, gastric cancer, uterine cancer, and lung cancers, as well as polyposis of the colon were 
Fig. 8 a MORB-normalized trace element diagram for the analyzed samples with normalizing values from Sun and McDonough (1989). b Chondrite-normalized REE diagram for the analyzed samples with normalizing values from Taylor and McLennan (1985) (Symbols are the same as those in Fig. 6a)
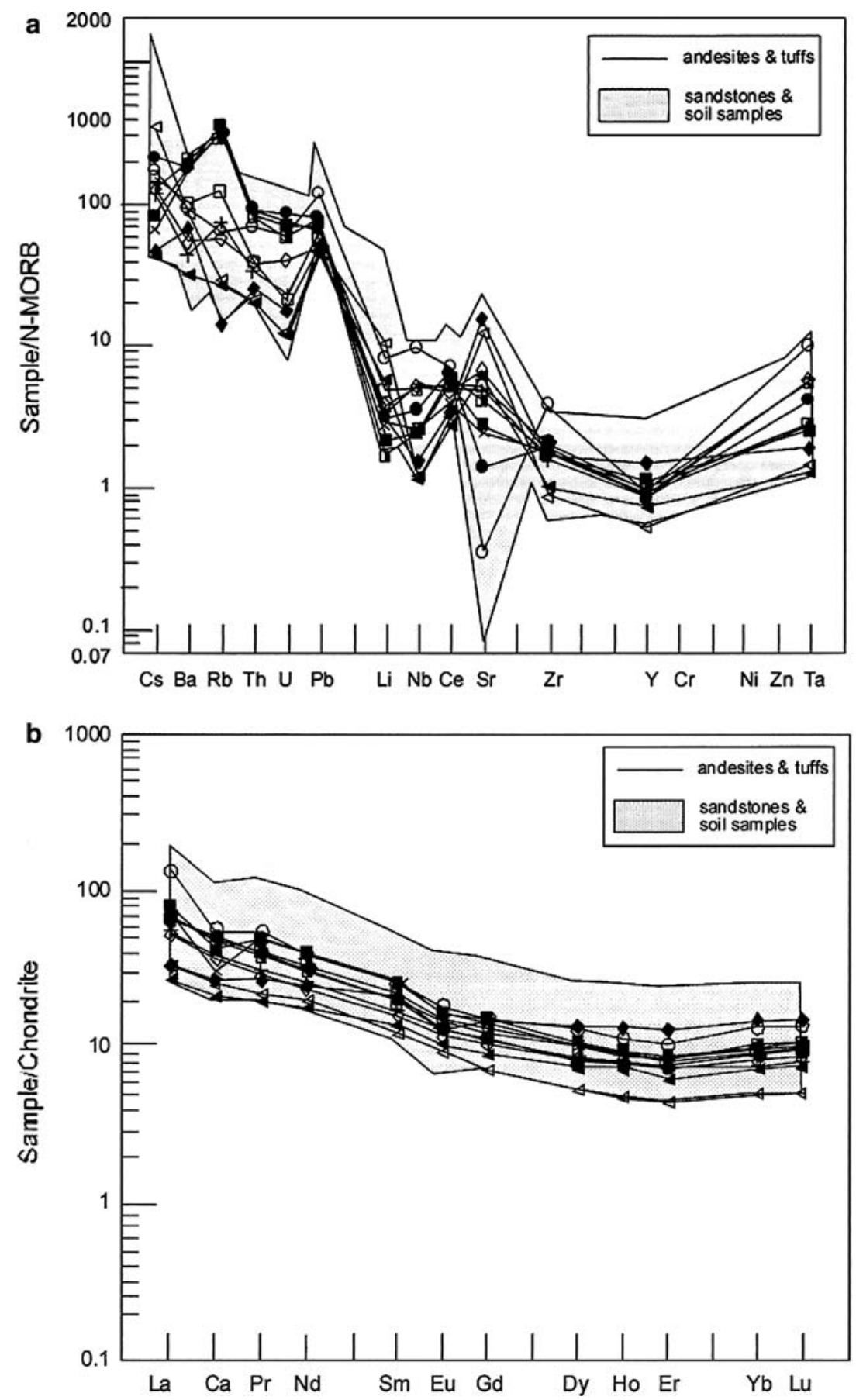

observed. Many individuals in the region died from different types of cancers at an early age. Detailed pedigree analysis documented a high degree of consanguineous marriages in the study population. The relationship of most of the cancer cases with consanguineous marriage was remarkable and suggested a genetic link to the cancer susceptibility in the region. One large family of 85 individuals, which began with a single ancestor and additional small pedigrees, was constructed during this analysis.
The proband had osteosarcoma with onset at the age of 20 years. Her brother had polyposis of the colon and her father died from pancreatic cancer at the age of 41 years. Her paternal aunt, and her three paternal uncles died from different types of cancers, but the ages at death were unknown for these family members. In the same pedigree, gastric cancer, uterine cancer, and lung cancer occurred in six distant relatives who had all died prior to the time of the study. Although it is difficult to estimate the exact mode of 


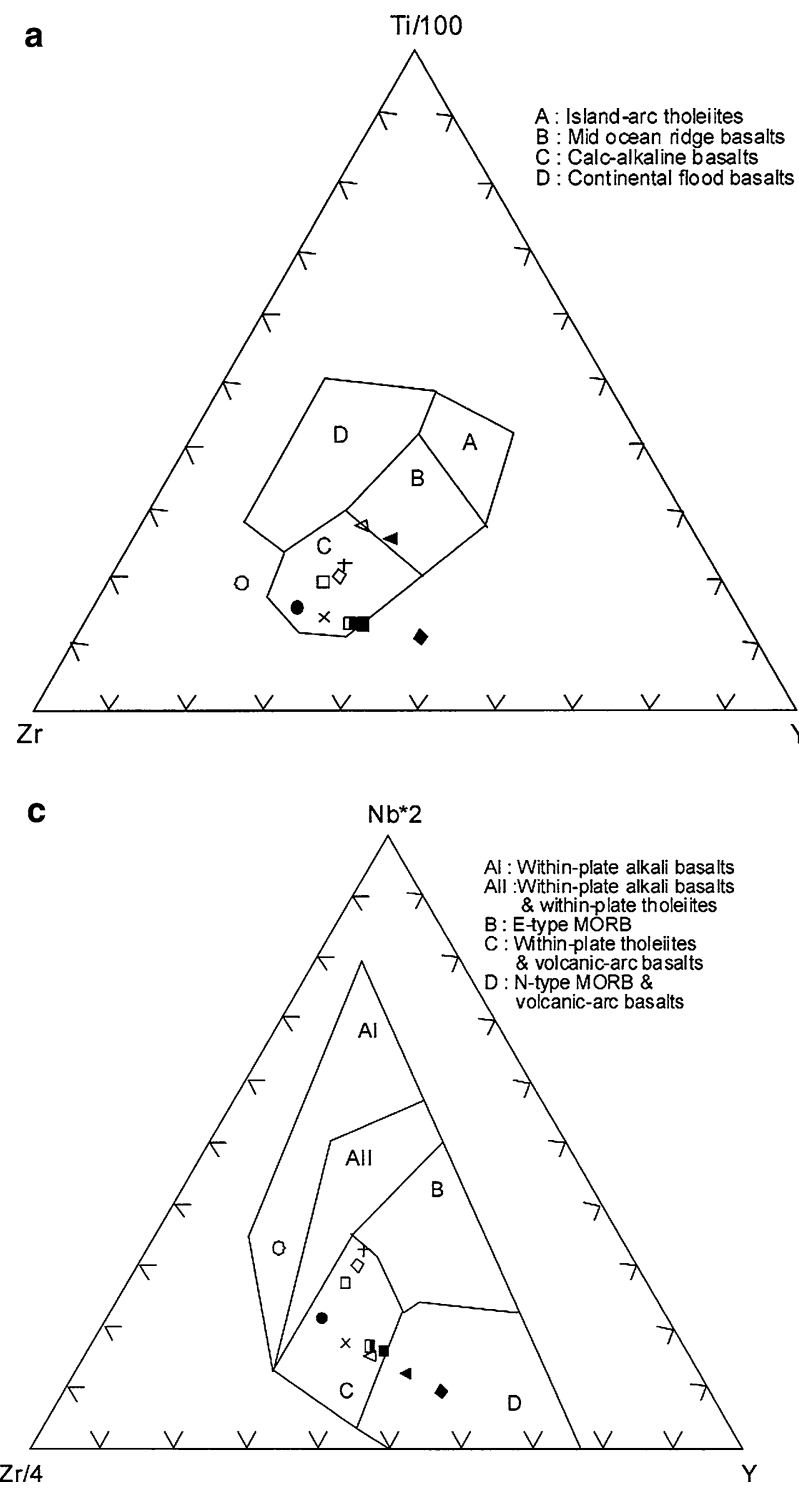

Fig. 9 Diagrams of the analyzed samples. a Ti*100-Zr-Y*3 diagram for andesites and tuffs (after Pearce and Cann 1973). b Ti versus $\mathrm{Zr}$ diagram for andesites and tuffs (after Pearce and Cann 1973). $\mathbf{c ~ N b * 2 - ~}$

inheritance, this large family met the criteria for diagnosis of Li-Fraumeni syndrome (LFS) as described by Li et al. (1988). Li-Fraumeni syndrome is an autosomal dominant cancer predisposition syndrome associated with soft tissue sarcoma, breast cancer, leukemia, osteosarcoma, and melanoma, as well as cancer of the colon, pancreas, adrenal cortex, and brain. More than $70 \%$ of individuals clinically diagnosed have an identifiable disease-causing mutation in the p53 gene (Chompret et al. 2000); however, DNAsequencing analysis of the entire coding region of p53 (exons 2-11) (Varley 2003) did not demonstrate any mutation using the peripheral blood of index osteosarcoma case.
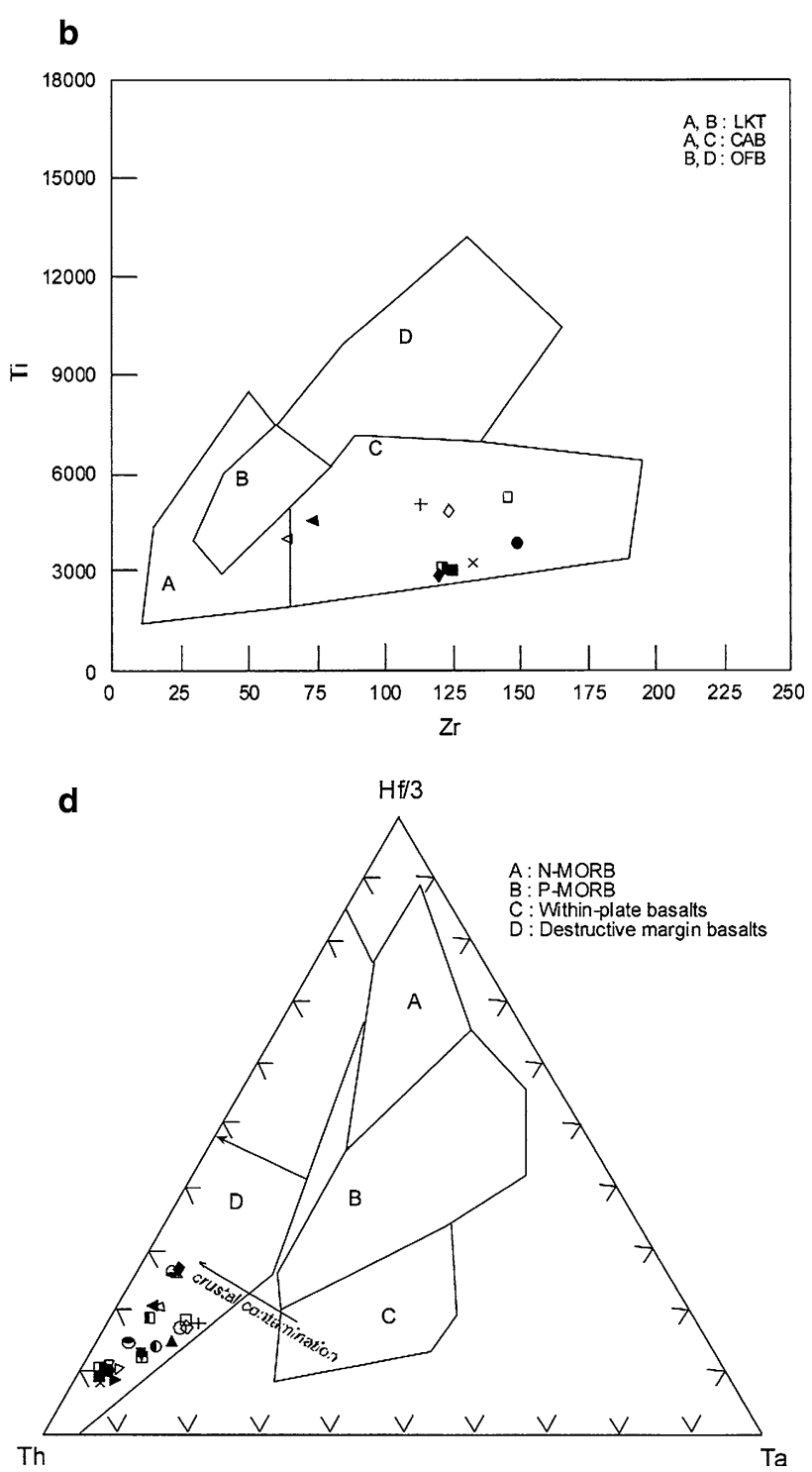

Zr/4-Y diagram for andesites and tuffs (after Meschede 1986). d Hf/3Th-Ta diagram (after Wood 1980) (Symbols are the same as those in Fig. 6a)

\section{Discussion}

The most widespread rocks in the Zonguldak region, which is situated in the western Black Sea Region, are volcanosedimentary rocks, including andesite, tuff, limestone, and sandstone. The geochemical study results suggest that the samples analyzed have subalkaline character, demonstrate the enrichment of incompatible elements $(\mathrm{Cs}, \mathrm{Ba}, \mathrm{Rb}, \mathrm{Th}$, $\mathrm{U}, \mathrm{K}$, and light REE), and possess almost flat, heavy REE patterns. They are comparable to island-arc calc-alkaline suites, and the enrichment in LILE relative to HFSE, and the depletion in $\mathrm{Ta}$ and $\mathrm{Nb}$, with respect to adjacent elements, indicate continental crust involvement in their 
genesis. Moreover, two petrographically and geochemically slightly different groups, which are represented by the Kazpınar and Dinlence formations, might suggest different magmatic sources.

Field observations and analytical determinations revealed that paleoclimatic conditions, as well as biological activities, resulted in the development of weathering processes in the volcano-sedimentary units of the study area. Alteration products, such as smectite, kaolinite, accessory chlorite, illite, mordenite, and analcime, are occasionally associated mainly with feldspar, quartz, opal-CT, amphibole, and calcite, and accessory olivine, serpentine, and dolomite. Additionally, kaolinization, chloritization, sericitization, and $\mathrm{Fe}-\mathrm{Ti}$-oxidation occurred in andesitic rocks and tuffaceous materials due to the degradation of an unstable glass shards matrix, and enclosed feldspar- and clinopyroxene-type phenocrysts developed, possibly due to diagenesis and hydrothermal activities followed mainly by weathering processes. Diagenesis and hydrothermal activities were supported by the presence of epidote, albite, zeolite, chlorite, and mica minerals (Chamley 1989). Similar alteration products can be seen in sandstones that are red in color due to Fe-Ti-oxidation. Micromorphologically, close associations of skeletal feldspar and relict glass shards with smectite and kaolinite, suborientation of feldspar-edged subparallel kaolinite plates to the fracture axes, along with the increase of plate sizes from the feldspar wall towards the fracture center reveal that the reaction of the water with feldspar and glass shards resulted in dissolution and precipitation of the released materials such as authigenic smectite or kaolinite (Berner and Holdern 1979; Kadir and Karakaş 2002; Mutlu et al. 2005). Dissolution of feldspar and glass shards resulted in the release of $\mathrm{Si}, \mathrm{Al}$, and $\mathrm{Mg}$ ions, which favored precipitation of smectite in a stagnant environment due to the concentration of such alkaline elements as $\mathrm{Ca}, \mathrm{K}$, and $\mathrm{Na}$. Petrographical studies (e.g., the presence of Na-, K-, and Ca-bearing minerals) and the results of the analysis of whole-rock geochemistry (e.g., the high abundance of $\mathrm{Ca}, \mathrm{K}$, and $\mathrm{Na}$, and high amount of LOI) are comparable with the results obtained through XRD and SEM results. The high rain fall and humidity of the Black Sea Region resulted in wetting of the volcano-sedimentary units close to the ground surface due to absorption, causing reduction of water flux in the fine-grained materials due to the expandability of the aggregate and reduction of the pores similar to what was reported by Velde (1995). On the other hand, kaolinite was formed in a drained acidic environment due to the removal of mobile alkaline elements by significant pore-water flux in large pores and desiccation cracks, possibly following drought. The formation of organic materials as a result of thick plant growth in the region, and the presence of calcified filaments and knobby microorganisms with alteration products may indicate that the biological processes that produced organic acid and $\mathrm{CO}_{2}$ might have also led to the dissolution of feldspar and glass shards, as well as the development of kaolinite (Klappa 1979; Curtis 1983; Surdam et al. 1984; Anand et al. 1985; Wright 1986; Beier 1987; Wright and Tucker 1991; Hurst and Pickering 1997).

Following the precipitation of smectite and/or kaolinite during the continuous dissolution of feldspar provided the pore waters with concentrations of excess $\mathrm{K}$ in comparison to the mobile $\mathrm{Na}$ and $\mathrm{Ca}$ ions that are leached out of the system. Such microenvironments may favor conversion of smectite to illite during diagenesis, as determined by the SEM analysis, which was also reported by Hower et al. (1976), Robertson and Lahann (1981), Bethke and Altaner (1986) and Rask et al. (1997). The main source of Fe and $\mathrm{Mg}$ for traces of chlorite is ferromagnesian minerals, such as pyroxene and amphibole. Changes to the $\mathrm{Na}, \mathrm{K}$, and $\mathrm{Ca}$ concentrations in the environment due to their mobility and pore water-flux, in addition to $\mathrm{Al}$, may also favor precipitation of mordenite and/or analcime.

Micromorphologically, the presence of fibrous minerals like mordenite may have a possible effect on the occurrence of cancer, although their contribution to the disease is not completely recognized and biological studies remain to be conducted (Klein 1993). A number of studies have generally indicated that amphibole asbestos is a more potent carcinogen than chrysotile asbestos since amphibole fibers penetrate deeper into the lungs, and persist in the lungs and adjacent tissues for longer periods of time than chrysotile, where they can trigger cancers and fibrosis (Plume et al. 2006). However, there is controversy concerning the pathogenicity of chrysotile, and a number of studies indicate that both chrysotile and amphibole asbestos forms are pathogenic (i.e., Lemen 2006). Moreover, a middle ground in this debate (Sporn and Roggli 2004) concludes that sufficient exposure to chrysotile may result in the development of cancer, but low levels are not likely to increase risk. Therefore, in our study, the presence of needle-type chrysotile in the residential buildings inhabited by cancer cases may have accelerated the development of the cancers.

On the other hand, cancer is a disease caused by genetic alterations in key target genes that provide a selective advantage to the growth of tumor cell. While cancer is a disease of mutations, it is generally not an inherited disease, like Duchenne muscular dystrophy or cystic fibrosis. Nearly all cancers are thought to arise from the interplay between inherited genetic alterations and the environment, and in the majority of cancers, environmental and genetic components are both involved in a complex, multifactor interaction, which is yet to be fully understood (Chen and Hunter 2005).

Cancer accumulation in a particular region first suggests an environmental cause. The hereditary component of such cases should always be considered in the study design for 
such regions. In the present study, based on family history, types of cancers observed in the region, early onset, and aggressive course of the cases, we considered one of the cancer predisposition syndromes, i.e., Li-Fraumeni syndrome. Although we did not find a germ line mutation in the p53 gene, which is the major cause of this syndrome, it is possible that there may be another gene that accounts for Li-Fraumeni syndrome. One such gene is human CHK2 (Bell et al. 1999). Heterozygote germ line mutations in the human CHK2 gene were demonstrated to be responsible for a small portion of $\mathrm{Li}$-Fraumeni patients; however, there are many families with similar manifestations that were not linked to either of these genes.

\section{Conclusions}

Our results clearly indicate that genetic variations in p53 gene did not influence the risk of cancer development in presented family. On the other hand, the segregation pattern of cancer susceptibility in the family strongly suggested a genetic influence of the increased cancer incidence in the region. Micromorphologically, the presence of fibrous mordenite in the altered units and needle-type chrysotile in the residential buildings, both of which are small enough to be inhaled, may have had a role in the expression of an unidentified gene, but are not the primary cause of cancer in this family. In summary, in this study, the effects of the geological environment on the health problems of one family in Gökçeler Village were studied, and it was concluded that the geological environment might have had a secondary role, but that genetic factors had a primary role in the development of disease in the region.

Acknowledgments This study was financially supported by the Cancer Control Department, Turkish Ministry of Health, and the Turkish Association for Cancer Research and Control, within the framework of the Terry-Fox Project. The authors are grateful to the General Directorate of Mineral Research and Exploration of Turkey (MTA) for conducting some of the mineralogical analyses. Professor Robert Hall and Dr. J. Nick Walsh (Royal Holloway, University of London) are greatly acknowledged for their help during chemical analysis and reviews of an early draft of the manuscript (by Professor Hall). Appreciation is extended to Huseyin Ozmen from Gökçeler Village, who together with most of his family was suffering from cancer, for his helps during the fieldwork. The authors are greatly indebted to Professor Gunter Doerhoefer, Editor-in-Chief, and anonymous reviewers for their critical reviews and suggestions, which improved the manuscript.

\section{References}

Arslan M, Kadir S, Abdioğlu E, Kolaylı H (2006) Origin and formation of kaolin minerals in saprolite of Tertiary alkaline volcanic rocks, Eastern Pontides, NE Turkey. Clay Miner 41:599-619
Abdioğlu E, Arslan M (2005) Mineralogy, geochemistry and genesis of the Ordu area bentonites, NE Turkey. Clay Miner 40:131-151

Akçay M (2004) Geochemistry of the footwall- and the hanging-wall dacite of the volcanogenic massive sulphide deposits in north eastern Turkey: a new exploration tool for the Kuroko type deposits. Ore Geol Rev (in review)

Anand RR, Gilkes RL, Armitage TM, Hillyer JW (1985) Feldspar weathering in lateritic saprolite. Clays Clay Miner 33:31-43

Beier JA (1987) Petrographic and geochemical analysis of caliche profiles in a Bahamian Pleistocene dune. Sedimentology 34:991998

Bell DW, Varley JM, Szydlo TE, Kang DH, Wahrer DCR, Shannon KE, Lubratovich M, Verselis SJ, Isselbacher KJ, Fraumeni JF, Birch JM, Li FP, Garbe JE, Haber DA (1999) Heterozygous germ line hCHK2 mutations in Li-Fraumeni syndrome. Science 286:2528-2531

Berner RA, Holdern GR (1979) Mechanism of feldspar weathering: some observational evidence. Geology 5:369-372

Bethke CM, Altaner SP (1986) Layer-by-layer mechanism of smectite illitization and application to a new rate law. Clays Clay Miner 34:136-145

Brindley GW (1980) Quantitative X-ray analysis of clays. Crystal structures of clay minerals and their X-ray identification. In: Brindley GW, Brown G (eds) Mineralogical Society Monograph, vol 5, London, pp 411-438

Bultman MW, Fisher FS, Pappagianis D (2005) The ecology of soil borne human pathogens. In: Selinus O, Alloway B, Centeno JA, Finkelman RB, Fuge R, Lindh U, Smedley P (eds) Essentials of medical geology: impacts of the natural environment on public health. Elsevier, London, pp 481-512

Chamley H (1989) Clay sedimentology. Springer, Heidelberg

Chen YC, Hunter DJ (2005) Molecular epidemiology of cancer. Cancer J Clin 55:45-54

Curtis C (1983) Geochemistry of porosity enhancement and reduction in clastic sediments. In: Brooks J (ed) Petroleum geochemistry and exploration of Europe. Geol Soc Lond Spec Publ 12:113-125

Çağatay MN (1993) Hydrothermal alteration associated with volcanogenic massive sulfide deposits: examples from Turkey. Econ Geol 88:606-621

Çelik M, Karakaya N, Temel A (1999) Clay minerals in hydrothermally altered volcanic rocks, eastern Pontides, Turkey. Clays Clay Miner 47:708-717

Chompret A, Brugieres L, Ronsin M, Gardes M, Dessarps-Freichey F, Abey A, Hua D, Ligot L, Dondon MG, Bressac-de Paillerets B, Frebourg T, Lemerle J, Bonaiti-Pellie C, Feuteun J (2000) P53 germline mutations in childhood cancers and cancer risk for carrier individuals, Br J Cancer 82:1932-1937

Folk RL (1974) Petrology of Sedimentary Rocks. Hemphill Publishing Company, Austin

Floyd PA, Winchester JA (1975) Magma type and tectonic setting discrimination using immobile elements. Earth Planet Sci Lett 27:211-218

Hillerdal G (2003) Health problems related to environmental fibreous minerals. In: Skinner HCW, Berger AR (eds) Geology and health. Oxford University Press, Oxford pp 113-118

Hower J, Eslinger EV, Hower M, Perry EA (1976) Mechanism of burial metamorphism of argilaceous sediments, I. Mineralogical and chemical evidence. Geol Soc Am Bull 87:725-737

Hurst VJ, Pickering Jr SM (1997) Origin and classification of coastal plain kaolins, southeastern USA, and the role of groundwater and microbial action. Clays Clay Miner 45:274-285

Iijima A (1980) Geology of natural zeolites and zeolitic rocks. In: Rees LVC (ed) Proceedings of the 5th international conference on Zeolites. Naples. Heyden and Co, London, pp 103-118

Iijima A, Tada R (1981) Silica diagenesis of Neogene diatomaceous and volcanoclastic sediments in northern Japan. Sedimentolgy 28:185-200 
Jones JB, Segnit ER (1971) The nature of opal I. Nomenclature and constituent phases. J Geol Soc Aust 18:57-68

Kadir S, Karakaş Z (2002) Mineralogy, chemistry and origin of halloysite, kaolinite and smectite from Miocene ignimbrites, Konya, Turkey. Neues Jahrbuch für Mineralogie. Abhandlungen 177:113-132

Klappa CF (1979) Calcified filaments in Quaternary calcretes: organo-mineral interactions in the subaerial vadose environment. J Sediment Petrol 49:955-968

Klein C (1993) Rocks, minerals and a dusty world. In: Guthrie GD Jr, Mossman BT (eds) Health effects of mineral dusts. Mineral Soc Am 28:7-59

Kuno H (1968) Differentiation of basalt magmas. In: Hess HH, Poldervaart A (eds) Basalts: the Poldervaart treatise on rocks of basaltlc composition, vol 2. Interscience, New York, pp 623-688

Leat PT, Jackson SE, Thorpe RS, Stillman CJ (1986) Geochemistry of bimodal basalt-subalkaline/peralkaline rhyolite provinces within the southern British Caledonides. J Geol Soc Lond 143:259-273

Lemen RA (2006) Epidemiology of asbestos-related diseases and the knowledge that led to what is known today. In: Asbestos: Dodson RF, Hammar SP (eds) Risk assessment, epidemiology, and health effects, Taylor and Francis, pp 201-308

Li FP, Fraumeni JR Jr, Mulvihill JJ, Blattner WA, Dreyfus MG, Tucker MA, Miller RW (1988) A cancer family syndrome in twenty-four kindreds. Cancer Res 48:5358-5362

MacEwan DMC, Wilson MJ (1980) Interlayer and intercalation complexes of clay minerals. In: Brindley GW, Brown G (eds) Crystal of clay minerals and their X-ray identification. Monograph of Mineralogical Society, London, pp 197-248

MacKenzie RC (1957) The differential thermal investigation of clays. Mineralogical Society, London

Meschede M (1986) A method of discriminating between different types of mid-ocean- ridge basalts and continental tholeiites with the Nb-Zr-Y diagram. Chem Geol 56:207-218

Moore DM, Reynolds RC (1989) X-ray diffraction and the identification and analysis of clay minerals. Oxford University Press, Oxford

Mutlu H, Sariiz K, Kadir K (2005) Geochemistry and origin of the Şaphane alunite deposit, western Anatolia, Turkey. Ore Geol Rev 26:39-50

Paterson E, Swaffield R (1987) Thermal analysis. In: Wilson MJ (eds) A handbook of determination methods in clay mineralogy. Blackie and Sons Limited, Chapman \& Hall, New York, pp 99-132

Pearce JA, Cann JR (1973) Tectonic setting of basic volcanic rocks determined using trace element analyses. Earth Planet Sci Lett 19:290-300

Plume GS, Morman SA, Ziegler TL (2006) The toxicological geochemistry of earth materials: an overview of processes and the interdisciplinary methods used to understand them. In: Sahai $\mathrm{N}$, Schoonen MAA (eds), Reviews in mineralogy and geochemistry. Mineral Soc Am 64:5-57

Rask JH, Bryndzia LT, Braunsdorf NR, Murray TE (1997) Smectite illitization in Pliocene-age gulf of Mexico mudrocks. Clays Clay Miner 45:99-109

Robertson HE, Lahann RW (1981) Smectite to illite conversion rates, effects of solution chemistry. Clays Clay Miner 29:129-135
Skinner HCW, Ross M, Frondel C (1988) Asbestos and other fibreous materials: mineralogy, crystal chemistry and health effects. Oxford University Press, New York

Smykatz-Kloss W (1974) Differential thermal analysis, application and results in mineralogy. Springer, Heidelberg

Sporn TA, Roggli VI (2004) Mesothelioma. In: Roggli VI, Oury TD, Sporn TA (eds) Pathology of Asbestos-Asbestos-associated diseases, 2nd edn. Springer, Heidelberg, pp 104-168

Sun SS, McDonough WF (1989) Chemical and isotopic systematics of oceanic basalts: implications for mantle composition and processes. In: Saunders AD, Norry MJ (eds) Magmatism in oceanic basins. Geol Soc Lond Spec Publ 42:313-345

Surdam RC, Boese SW, Grossey LJ (1984) The chemistry of secondary porosity. In: McDonald DA, Surdam RC (eds) Clastic diagenesis, 37. American Association of Petroleum Geologists Mem, US, pp 127-150

Taylor SR, McLennan SM (1985) The continental crust: its composition and evolution. Blackwell, Oxford

Tüysüz O (1999) Geology of the cretaceous sedimentary basins of the Western Pontides. Geol J 34:75-93

Tüysüz O, Aksay A, Yiğitbaş E (2004) Batı Karadeniz bölgesi litostratigrafi birimleri serisi-1. Ankara: Maden Tetkik ve Arama Genel Müdürlüğü 1-73

Varley JM (2003) Germline TP53 mutations and Li-Fraumeni syndrome. Hum Mutat 21:313-20

Velde B (1985) Clay minerals: a physico-chemical explanation of their occurrence. In: Developments in sedimentology, vol 40. Elsevier, Amsterdam

Velde B (1995) Origin and mineralogy of clays. Clays and the environment. Springer, Heidelberg

Wilson MJ (1987) X-ray powder diffraction methods. In: Wilson MJ (ed) A handbook of determinative methods in clay mineralogy. Blackie, Glasgow, pp 26-98

Winchester JA, Floyd PA (1977) Geochemical discrimination of different magma series and their differentiation products using immobile elements. Chem Geol 20:325-343

Wood DA (1980) The application of a Th-Hf-Ta diagram to problems of tectonomagmatic classification to establishing the nature of crustal contamination of basaltic lavas of the British Tertiary volcanic province. Earth Planet Sci Lett 50:11-30

Wright VP (1986) The role of fungal biomineralization in the formation of Early Carboniferous soil fabrics. Sedimentology 33:831-838

Wright VP, Tucker ME (1991) Calcretes. The International Association of Sedimentologist, Oxford

Yalçın H, Gümüşer G (2000) Mineralogical and geochemical characteristics of Late Cretaceous bentonite deposits of the Kelkit Valley Region, Northern Turkey. Clay Miner 35:807-825

Yergök AF, Akman Ü, İplikçi E, Karabalık NN, Keskin İ, Mengi H, Umut M, Armağan F, Erdoğan K, Kaymakçı H, Çetinkaya A (1987) Batı Karadeniz bölgesinin jeolojisi (1). Ankara: Mineral Research and Exploration Institude of Turkey (MTA) Report no: 8273 (in Turkish, unpublished) 